\title{
DIAZEPAM IN ACUTE STROKE
}


Some studies in this thesis were financially supported by the Profileringsfonds AZM.

The publication of this thesis was financially supported by: Novartis, Serono, TEVA Pharma, Boehringer- Ingelheim, GlaxoSmithKline

ISBN-10: 90-9021053-9

ISBN-13: 978-90-9021053-7

Printed by: Datawyse / Universitaire Pers Maastricht

(C) Copyright 2006, L.A.M. Aerden, Maastricht, The Netherlands

All rights are reserved, whether the whole or part of the material is concerned. No part of this publication may be reproduced, stored in a retrieval system, or transmitted in any form or by any means, electronic, mechanical, photocopying, recording or otherwise, without written permission from the copyright owner. 


\title{
Diazepam in acute stroke
}

\author{
PROEFSCHRIFT
}

ter verkrijging van de graad van doctor aan de Universiteit Maastricht, op gezag van de Rector Magnificus,

Prof. mr. G.P.M.F. Mols

volgens het besluit van het College van Decanen, in het openbaar te verdedigen

op vrijdag 8 december 2006 om 12:00 uur

door

Leo Adrianus Maria Aerden

geboren te Roosendaal en Nispen op 9 mei 1968 


\section{Promotores}

Prof.dr. H.W.M. Steinbusch

Prof.dr. J.S.H. Vles

\section{Copromotor}

Dr. E.P.M. van Raak

\section{Beoordelingscommissie:}

Prof.dr. M. Limburg (voorzitter)

Prof.dr. M. Borgers

Dr. S.F.T.M. de Bruijn (Haga Ziekenhuis, Den Haag)

Prof.dr. W. Mess

Prof.dr. J. Wilmink 


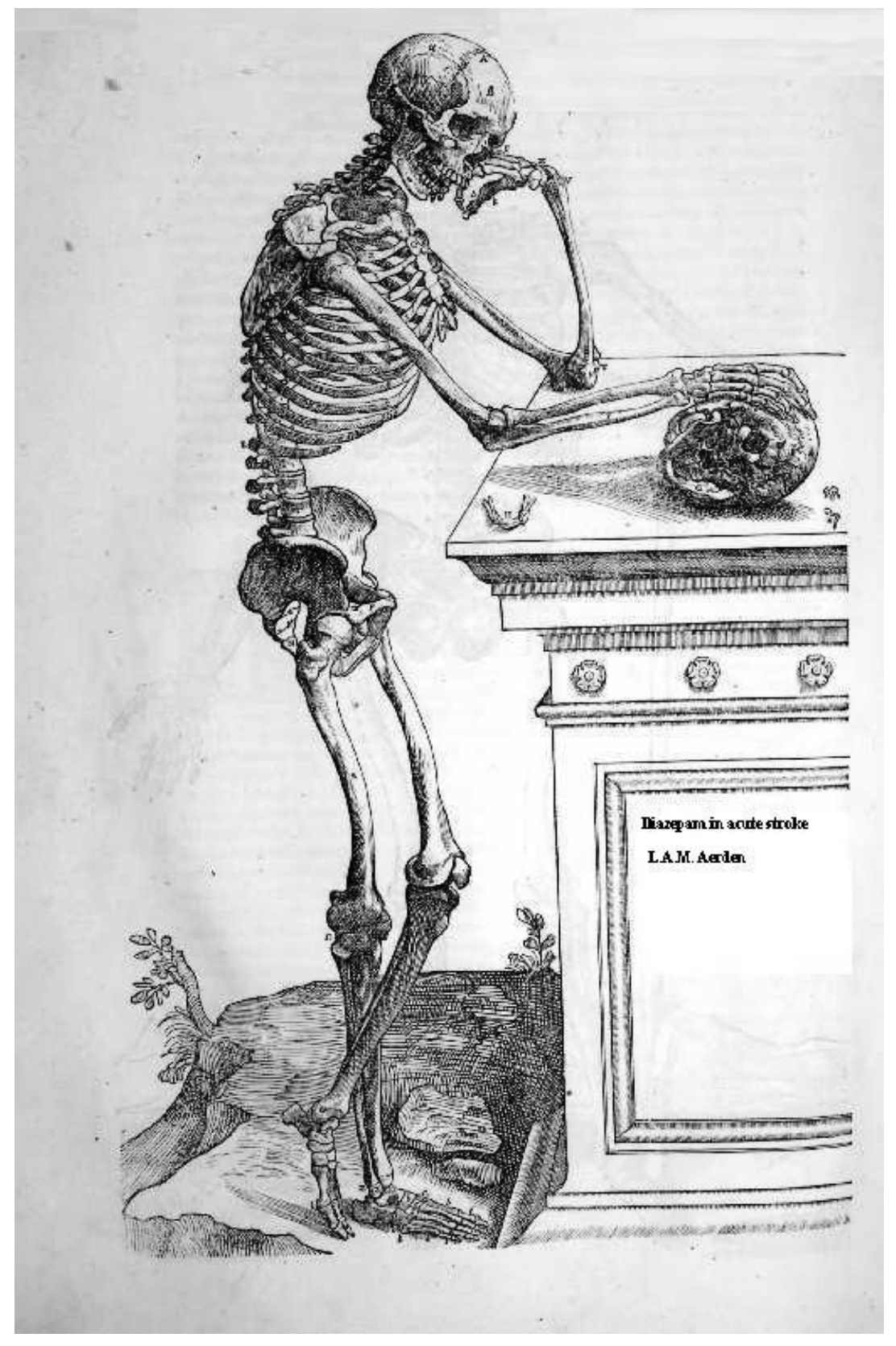

Naar Andreas Vesalius (1514-1564) 

Aan Mirjam, aan Wouter Domingo 



\section{Contents}

$\begin{array}{ll}\text { List of abbreviations } & 11\end{array}$

$\begin{array}{ll}\text { Samenvatting } & 13\end{array}$

$\begin{array}{ll}\text { Summary } & 17\end{array}$

$\begin{array}{ll}\text { Chapter } 1 & 21\end{array}$

General introduction

$\begin{array}{ll}\text { Chapter } 2 & 29\end{array}$

Diazepam reduces brain lesion size in a photothrombotic model of focal ischemia in rats

Chapter 3

Dual effect of diazepam on cGMP levels in rat brain slices

\section{Chapter 4}

Validation of the Oxfordshire Community Stroke Project syndrome diagnosis derived from a standard symptom list in acute stroke.

\section{Chapter 5}

Diazepam in acute stroke; any harm? A randomised, double blind, placebo controlled safety study in 865 patients from the EGASIS (Early GABA-ergic Activation Study In Stroke) trial

\section{Chapter 6}

Common drugs in acute ischemic stroke and their influence on outcome. An observational study in 1013 stroke patients

\section{Chapter 7}

General Discussion

Dankwoord 


\section{List of abbreviations}

ACE Angiotensin-Converting Enzyme

cAMP cyclic Adenosine-Mono-Phosphate

AMPA $\quad \alpha$-amino-3-hydroxy-5-methyl-4-isoxazole-propionic-acid

AT Athero-thrombotic

CE Cardio-embolic

GABA Gamma-amino-butyric-acid

cGMP cyclic Guanosine-Mono-Phosphate

sGC soluble Guanylate Cyclase

IBMX 3-Isobutyl-1-methylxanthine

$\mathrm{ICH} \quad$ Intra Cerebral Haemorrhage

LACS Lacunar Syndrome

L-NAME $\quad \mathrm{N}^{\mathrm{G}}$-nitro-L-arginine methylester

NMDA N-methyl-D-Aspartate

NO Nitric Oxide

NOS Nitric Oxide Synthetase

OCSP Oxfordshire Community Stroke Project

PACS Partial Anterior Circulation Syndrome

PDE Phosphodiesterase

POCS Posterior Circulation Syndrome

SNP Sodium Nitropruside

TACS Total Anterior Circulation Syndrome

rTPA recombinant Tissue Plasminogen Activator 


\section{SAMENVATTING}




\section{Samenvatting}

Diazepam is een veelbelovende stof die de hersenen mogelijk zou kunnen beschermen tegen de gevolgen van ischemie. Vanuit het academisch ziekenhuis Maastricht werd een grootschalige vergelijkende studie opgezet naar de effectiviteit van dit middel als neuroprotectivum in de klinische setting. In voorbereiding op, en deels parallel aan deze studie bestonden de volgende vragen: is diazepam neuroprotectief bij focale ischemie? Zo ja, op welke wijze? Is het veilig om diazepam toe te dienen aan patiënten in de acute fase van een herseninfarct? Bestaat er een methode om de aard en ernst van een beroerte betrouwbaar te vergelijken in verschillende behandelcentra? Zijn er nog andere veelgebruikte geneesmiddelen die een invloed op de prognose zouden kunnen hebben? In de volgende hoofdstukken worden deze vragen beantwoord. In hoofdstuk twee wordt aangetoond, dat diazepam, in een proefdiermodel, een beschermend effect heeft. Het betreft een effect op de grootte van een photothrobotisch geïnduceerd infarct. Dit echter alleen wanneer diazepam tenminste een uur of vier uur na het ontstaan van ischemie wordt toegediend. Dit effect op de grootte van het infarct kan deels worden verklaard door de bekende werking van diazepam op de GABA-receptor. GABA voorkomt het vrijkomen van glutamaat, en gaat de werkzaamheid tegen. Dit is een proces dat vroeg optreedt na het ontstaan van ischemie. Het feit dat dit effect alleen optreedt wanneer diazepam na enige tijd wordt toegediend wijst erop dat ook andere mechanismen later in de chemische cascade een rol spelen. In hoofdstuk drie worden deze mechanismen onderzocht. Gebleken is dat diazepam het cGMP gehalte in het cerebellum verlaagt. Dit effect is dosisafhankelijk en wordt waarschijnlijk veroorzaakt door een effect op oplosbaar guanylyl cyclase. In gliacellen lijkt het cGMP intracellulair juist toe te nemen door de aanwezigheid van diazepam. Dit wordt waarschijnlijk veroorzaakt door een effect op PDE-4. Het lijkt aannemelijk dat diazepam inderdaad ook de stappen later in de ischemische cascade beïnvloed. Het effect van een potentieel neuroprotectieve stof zou kunnen afhangen van de soort beroerte. De OCSP classificatie onderscheidt subgroepen met een verschillende prognose door middel van een symptoomlijst. Om de aard van de beroerte in verschillende centra te kunnen vergelijken is in hoofdstuk vier een validatie studie uitgevoerd waarin een lijst met symptomen zoals gebruikt in het OCSP project werd vergeleken met de klinische diagnose van een ervaren neuroloog. Hieruit blijkt dat de lijst uit de OCSP studie een betrouwbaar middel is om een classificatie van de beroerte te maken. In hoofdstuk vijf wordt vervolgens aandacht besteed aan enkele publicaties waarin de veiligheid van de toediening van diazepam in de acute fase van een beroerte ter discussie werd gesteld. Om die reden zijn tijdens de EGASIS studie $(n=865)$ alle mogelijke bijwerkingen van diazepam geregistreerd. Een derde van alle patiënten met een ischemische beroerte maakte een episode door met een bijwerking die mogelijk was toe te schrijven aan het gebruik van diazepam. Er was echter geen verschil tussen behandelde en niet behandelde patiënten. Bij patiënten met een hersenbloeding was het aantal longontstekingen wel significant hoger in de behandelde groep. Geconcludeerd wordt dat diazepam veilig kan worden toegediend in de eerste dagen na een ischemische beroerte. Bij patiënten met een hersenbloeding dient men echter terughoudendheid te betrachten. Om nieuwe potentiële neuroprotectieve 
middelen te ontdekken wordt in hoofdstuk zes het effect op de functionele toestand na drie maanden onderzocht van andere middelen die vaak worden voorgeschreven in de oudere populatie, en die dus vaak aanwezig zijn op het moment dat een beroerte optreed. Het blijkt dat er een verband bestaat tussen het gebruik van vaatverwijdende middelen bij het begin van de beroerte en een slechte toestand van de patiënt met een lacunair syndroom na drie maanden. Verder heeft het gebruik van diuretica een relatie met een slechte toestand na drie maanden bij beroertes met een athero-thrombotische origine. Het gebruik van calcium antagonisten daarentegen heeft een relatie met een goed herstel na drie maanden bij patiënten met een beroerte van cardio-embole oorsprong. De werkzaamheid van diazepam als neuroprotectivum bij een beroerte is in dit proefschrift aannemelijk gemaakt. De resultaten van de EGASIS studie, die elders gepubliceerd zijn, bevestigen dit. Het is veilig om diazepam toe te dienen in de acute fase van een ischemische beroerte. 
SUMMARY 


\section{Summary}

Diazepam is a promising neuroprotective drug that might protect the brain from the consequences of ischemia. To test the neuroprotective effects of diazepam in the clinical setting, a double blind, randomised, placebo-controlled multicentre trial was organised at Maastricht University. In preparation and partially parallel to a clinical trial with diazepam (EGASIS) we had some questions. Does diazepam have neuroprotective effects in focal ischemia? How does it work? Is it safe to administer in the acute phase of stroke? Is it possible to uniformly categorise infarct subtype in different hospitals? Are there other commonly used drugs that have an influence on functional outcome when used at stroke onset? In the following chapters we deal with these questions.

In Chapter two we evaluated the neuroprotective effects of diazepam in an animal model of focal ischemia. We found an effect on lesion size when administered one and four hours after, but not before the onset of focal brain ischemia. This neuroprotective effect can partially be explained by the well-known effect of diazepam on the GABA-receptor. GABA prevents the release of glutamate, and counteracts its effects. This is a very early event in the excitotoxic cascade. As the effect on lesion size was only seen when diazepam was administered after a delay, we studied whether there was an additional effect of diazepam somewhat later in the excitotoxic cascade in chapter three. We found that diazepam dose-dependently decreased cGMP synthesis in cerebellar slices probably due to an effect on soluble guanylyl cyclase. In addition we observed increased cGMP immunoreactivity in glial cells in the cerebellum, the hippocampus, and the cerebral cortex probably secondary to inhibition of phosphodiesterase-4. It seems that diazepam indeed has additional neuroprotective effects along the pathway of glutamate neurotoxicity.

Any neuroprotective effect of diazepam might depend on stroke subtype. The Oxfordshire Community Stroke Project (OCSP) classification allows distinction of stroke subtypes with different prognosis with a standard symptom list. The validity against clinical diagnosis was established in chapter four.

There were some reports that diazepam could be harmful in acute ischemic stroke. Therefore in chapter five we evaluated safety aspects in the EGASIS trial. In ischemic stroke we found in over one-third of our stroke patients $(\mathrm{n}=865)$ at least one of the defined potential treatment side effects in both diazepam and placebo treated patients. In those with $\mathrm{ICH}$, however, pneumonia was registered significantly more often in the diazepam group. In chapter five we conclude that diazepam is safe in focal cerebral ischemia but should be avoided in haemorrhagic stroke.

In chapter six we evaluate the neuroprotective effects of various drugs often present at stroke onset, as independent predictors of outcome at three months in order to discover new potentially neuroprotective agents. Vasodilator use was associated with functional dependence at three months in lacunar stroke. The use of diuretics was independently associated with functional dependence in atherothrombotic stroke. Calcium blockers were independently associated with better outcome at three months in cardio-embolic stroke. 
We conclude that diazepam is a promising neuroprotective drug. It is safe to administer in the acute phase of ischemic stroke. The EGASIS trial that was published elsewhere confirms our findings. 
CHAPTER 1

\section{General Introduction}




\section{General Introduction}

Stroke is one of the leading causes of death and disability in the Western world $[1,2]$. It not only ranks third as cause of death, but also is one of the main causes of permanent physical and cognitive disability [3]. Any agent that could ameliorate prognosis even modestly would be of major importance. During the last decades important steps have been made towards an evidence-based approach in the treatment of stroke. Various methods for secondary stroke prevention have proven to be effective. Carotid endarterectomy in embolic stroke [4] and the use of anticoagulants in atrial fibrillation [5] have found their way in clinical practice and are now undisputed. Antihypertensive and lipid lowering drugs recently have proven to be effective in the risk reduction of recurrent stroke, not only in patients who were expected to benefit from antihypertensive or lipid lowering treatments, but also in those without hypertension or elevated serum cholesterol [6,7]. Finally, there is a modest place for new antithrombotic drugs [8,9]. Time will learn whether high expectations will be confirmed.

Acute stroke treatment has also made an important step forward. The establishment of stroke units improved prognosis for functional outcome and survival significantly [10]. In The Netherlands acute stroke care in almost every hospital is currently organised in this way. Treatment in acute stroke can roughly be divided into two strategies: therapies based on the aim to establish reperfusion, and neuroprotection. Early reperfusion by intravenous thrombolysis with rTPA has become a standard treatment in ischemic stroke in a small group of well selected patients [11]. Intra-arterial thrombolysis is performed in selected patients in some centres, but is still in the experimental phase [12]. As promising as the results may be, it seems unlikely that this treatment will be available very soon for the stroke population at large. The large group that cannot be treated by these techniques urge for a new treatment that could extent the therapeutic time window during which reperfusion could take place, either spontaneous or by thrombolysis. Neuroprotective agents might have this intended effect, and may also improve prognosis by themselves in these patients.

The concept of neuroprotection and neurotoxicity was first described by Olney in 1971 [13]. He described a cascade of chemical reactions that take place after the onset of ischemia and that, at least in theory, could be reversed or stopped. Glutamate, calcium and nitric oxide (NO) play a central role, but also the GABA-system is an essential part of this cascade (fig.1). The concept is summarised as follows: Ischemia results in energy failure that leads presynaptically to an accumulation of positive ions, which triggers the release of excitatory amines like glutamate into the interstitium. These neurotransmitters activate postsynaptic receptors of which the NMDA receptor is one of the most powerful regulators of cellular calcium homeostasis. This postsynaptic stimulation results in a massive influx of calcium into the cell that on its turn activates a number of enzyme systems that produce $\mathrm{NO}$ and free radicals. These products lead to the breakdown of cellular integrity and cell death. Numerous experimental studies targeting at different steps in the described cascade showed promising results, but clinical trials failed to show a significant effect on outcome in the clinical setting. Most of the drugs tested so far were especially de- 
veloped as potential neuroprotectants. They were often targeted at a single step in this complex excitotoxic cascade. The NMDA receptor was one of the most popular aims for potential neuroprotective drugs, because it was considered to be one of the key elements in the excitotoxic process. Under ischemic conditions however, not only the NMDA receptor is important in relation to the cellular accumulation of positively charged ions, but also various other mechanisms including voltage-gated ion channels and non-NMDA (AMPA) receptors, play a role. As NMDA receptor activation is a very early event following ischemia, interference with other processes further along the chain may be more effective. For example through agents inhibiting NO-formation, or agents having an influence on phosphodiesterases (PDE's) that counteract the effect of cGMP and NO. In line with this idea, recently, a free radical scavenger (NXY-059), exerting its effect very late in the cascade, appeared to have a slight effect on functional outcome in human stroke [14]. Probably, however, the most effective interference is targeting at different steps in the cascade simultaneously.

Fig.1 The excitotoxic cascade.
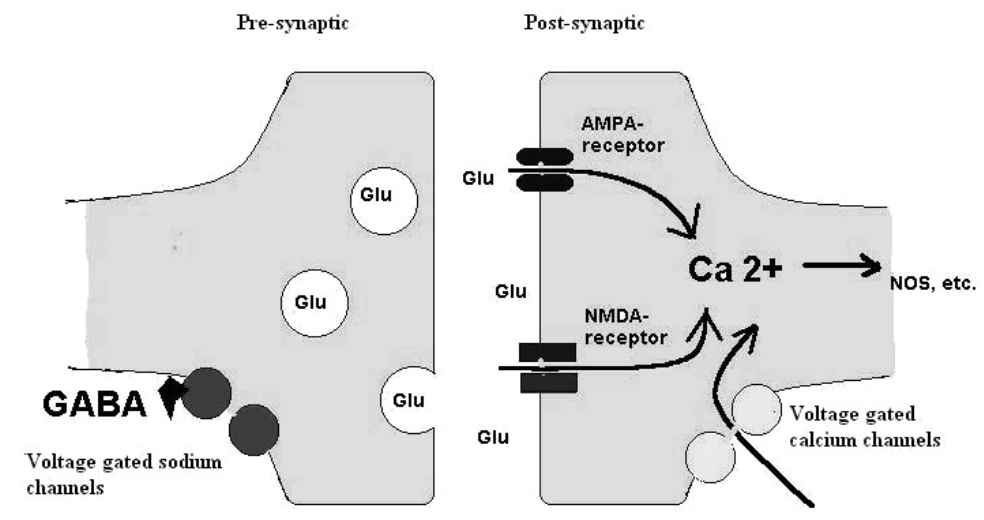
Diazepam is a functional GABA-agonist. Theoretically, GABA-ergic stimulation counteracts the consequences of the glutamate release because of a GABAmediated repolarisation of the pre- and post-synaptic membrane. Nevertheless a large trial with clomethiazole, a GABA-ergic drug, showed no effect on prognosis in human stroke [16]. It appears that brain ischemia by itself leads to an increase of extracellular GABA-levels within minutes [17]. However, under ischemic conditions the affinity of the GABA receptor is decreased [18,19], and therefore the most rational strategy to increase GABA-ergic activity would not be increasing the amount of GABA but the receptor's affinity for it. Diazepam enhances the GABAreceptor, increasing $\mathrm{Cl}^{-}$influx and thus stabilising the cell membrane. It prevents depolarisation of the presynaptical as well as the postsynaptic cell, thus acting as a functional glutamate antagonist. Furthermore, diazepam lowers cell metabolism resulting in a decreased build-up of toxic by-products of anaerobic glycolysis. It also increases cerebral blood flow in the penumbra through vasodilatation of collateral vessels [20]. Therefore, it is a promising neuroprotective drug. It's neuroprotective effect has been demonstrated in global ischemia models in vivo and in vitro $[21,22]$, and recently also in human cardio-embolic stroke [15]. A large, multicentre, randomised, double-blind, placebo-controlled clinical trial in acute stroke patients was co-ordinated from our centre, to test the neuroprotective properties of diazepam by measuring its effect on functional outcome at three months. This EGASIS trial has been terminated by now, and the results are published elsewhere [15]. Simultaneously with the EGASIS trial, the studies that are described in this thesis, were performed, to answer several questions we still had on the neuroprotective action of diazepam and its safety profile in acute stroke patients.

We studied the effects of diazepam on infarct size in a rat model of focal ischemia in Chapter two, and whether such effect depended on the time point of diazepam administration. In Chapter three we tested the hypothesis that the effect of diazepam in ischemic stroke not only arises from it's capacity to increase the receptor's affinity for GABA, and thus glutamate inhibiting effect, but that other mechanisms along the ischemic cascade, like inhibition of NO, play an additional role. Therefore we investigated the influence of diazepam on the formation of NO in this chapter. In the cerebellum, glutamate-induced NO levels and, subsequently the cGMP levels, are high compared to other brain regions. Therefore, we initially studied the effect of diazepam on cGMP levels in rat cerebellar tissue slices, using cGMPimmunocytochemistry. This technique not only permits the localisation of cGMP containing cells, but can also be used in a quantitative way [23]. In addition we studied the effects of diazepam on cGMP levels in cerebral cortex and hippocampus in slices of rat brain.

Any future neuroprotective drug should at least be safe to administer in acute stroke patients. The EGASIS trial offered us a unique opportunity to study the safety of an early three-day diazepam treatment in almost 900 acute stroke patients, in a doubleblind, placebo-controlled way. To prove that the administration of diazepam was at least safe, we recorded all adverse and serious adverse events that occurred in the first two weeks in the different treatment groups of the EGASIS trial (placebo ver- 
sus diazepam $2 \mathrm{dd} 10 \mathrm{mg}$ ). This safety study on early diazepam treatment in acute stroke patients is described in Chapter five.

For practical reasons it was very important that we had a reliable method to compare stroke severity in the different participating centres of the EGASIS trial. That is why we performed a validation study with the OCSP-scoring list, which is described in Chapter four. The OCSP-scoring list is a small list with 12 items to be scored that gives an indication of the stroke syndrome and severity. By doing this we hoped to acquire a simple and reliable instrument to uniformly establish the different subgroups of ischemic stroke.

Diazepam is frequently prescribed in the elderly and is often used at stroke onset. Not only diazepam but also a wide variety of different drugs used during the acute phase of stroke may improve or worsen stroke outcome. The arguments pro or con the use of certain drugs during the acute stroke phase mainly stem from theoretical considerations and animal experiments, whereas clinical evidence is scarce. Therefore, in an observational study of 1013 acute ischemic stroke patients, which is described in Chapter six, we studied the use of various drugs on admission as independent predictors of functional outcome at three months.

In summary, the purposes of this thesis are:

- $\quad$ to demonstrate that diazepam has neuroprotective effects in a focal ischemia model in rats (Chapter 2)

- $\quad$ to explore whether such neuroprotective effect depends on the time point of diazepam administration (Chapter 2)

- to investigate whether the neuroprotective effect of diazepam is due to its well-known GABA-ergic effect, or that additional steps that take place later in the excitotoxic cascade are influenced by diazepam (Chapter 3 )

- $\quad$ to develop a simple and reliable scoring list to uniformly establish stroke severity and the different subgroups of ischemic stroke (Chapter 4)

- $\quad$ to determine the safety of early diazepam treatment in acute stroke patients (Chapter5)

- $\quad$ to search for other commonly used drugs that may be promising neuroprotective agents in human stroke and that could be included in our animal models and clinical trials, or that should rather be avoided during the early post-stroke period (Chapter 6) 


\section{References}

1. www.CBS.nl

2. Kimura K, Minematsu K, Kazui S, Yamaguchi T. Japan Multicenter Stroke Investigators' Collaboration (J-MUSIC): Mortality and cause of death after hospital discharge in 10,981 patients with ischemic stroke and transient ischemic attack. Cerebrovasc Dis. 2005;19:171-8.

3. Hankey GJ, Jamrozik K, Broadhurst RJ, Forbes S, Anderson CS: Long-term disability after firstever stroke and related prognostic factors in the Perth Community Stroke Study, 1989-1990 Stroke. 2002; 33:1034-40.

4. The European Carotid Surgery Trialists'Collaborative group. Randomised trial of endarterectomy for recently symptomatic carotid stenosis: final results of the MRC European Carotid Surgery Trial (ECST). Lancet. 1998; 351: 1379-87.

5. EAFT (European Atrial Fibrillation Trial) Study Group. Secondary prevention in non-rheumatic atrial fibrillation after transient ischaemic attack or minor stroke. Lancet. 1993; 342:1255-62.

6. The Long-Term Intervention with Pravastatin in Ischaemic Disease (LIPID) Study Group. Prevention of cardiovascular events and death with pravastatin in patients with coronary heart disease and a broad range of initial cholesterol levels. N Engl J Med. 1998 339:1349-57.

7. Poulter NR, Wedel H, Dahlof B, Sever PS, Beevers DG, Caulfield M, Kjeldsen SE, Kristinsson A, McInnes GT, Mehlsen J, Nieminen M, O'Brien E, Ostergren J, Pocock S; ASCOT Investigators. Role of blood pressure and other variables in the differential cardiovascular event rates noted in the Anglo-Scandinavian Cardiac Outcomes Trial-Blood Pressure Lowering Arm (ASCOT-BPLA). Lancet. 2005; 366: 907-13.

8. CAPRIE Steering Committee. A randomised, blinded, trial of clopidogrel versus aspirin in patients at risk of ischaemic events (CAPRIE). Lancet. 1996 348: 1329-39.

9. Diener HC, Cunha L, Forbes C, Sivenius J, Smets P, Lowenthal A European Stroke Prevention Study. 2. Dipyridamole and acetylsalicylic acid in the secondary prevention of stroke. J Neurol Sci. 1996; 143: 1-13.

10. Langhorne P, Williams BO, Gilchrist W, Howie K Do stroke units save lives? Lancet. 1993 Aug 14;342(8868):395-8.

11. Hacke W, Kaste M, Fieschi C, von Kummer R, Davalos A, Meier D, Larrue V, Bluhmki E, Davis S, Donnan G, Schneider D, Diez-Tejedor E, Trouillas P. Randomised double-blind placebo-controlled trial of thrombolytic therapy with intravenous alteplase in acute ischaemic stroke (ECASS II). Second European-Australasian Acute Stroke Study Investigators. Lancet. 1998; 352: 1245-51.

12. Kim DJ, Kim DI, Kim SH, Lee KY, Heo JH, Han SW. Rescue localized intra-arterial thrombolysis for hyperacute MCA ischemic stroke patients after early non-responsive intravenous tissue plasminogen activator therapy. Neuroradiology. 2005; 47: 616-21.

13. Olney, J.W., Ho, O.L. \& Rhe, V. Cytotoxic effects of acidic and sulphur-containing amino-acids on the infant mouse central nervous system. Exp. Brain Res. 14, 61-67.

14. Lees KR, Zivin JA, Ashwood T, Davalos A, Davis SM, Diener HC, Grotta J, Lyden P, Shuaib A, Hardemark HG, Wasiewski WW; Stroke-Acute Ischemic NXY Treatment (SAINT I) Trial Investigators. NXY-059 for acute ischemic stroke. N Engl J Med. 2006; 354: 588-600. 
15. Lodder J, van Raak L, Hilton A, Hardy E, Kessels A; EGASIS Study Group. Diazepam to improve acute stroke outcome: results of the early GABA-Ergic activation study in stroke trial. a randomized double-blind placebo-controlled trial. Cerebrovasc Dis. 2006; 21:120-7.

16. Lyden P, Shuaib A, Ng K, Levin K, Atkinson RP, Rajput A, Wechsler L, Ashwood T, Claesson L, Odergren T, Salazar-Grueso E; CLASS-I/H/T Investigators. Clomethiazole Acute Stroke Study in ischemic stroke (CLASS-I): final results. Stroke. 2002;33: 122-8.

17. Globus MY, Busto R, Dietrich WD, Martinez E, Valdes I, Ginsberg MD. Effect of ischemia on the in vivo release of striatal dopamine, glutamate, and gamma-aminobutyric acid studied by intracerebral microdialysis. J Neurochem. 1988; 51: 1455-64.

18. Akaike N, Inomata N, Tokutomi N. Contribution of chloride shifts to the fade of $\gamma$-aminobutyric acid-gated currents in frog dorsal root ganglion cells. J Physiol (Lond) 1987;391:219-234.

19. Twyman RE, MacDonald RL. Antieplileptic drug regulation of $\mathrm{GABA}_{\mathrm{A}}$ receptor channels. In: Tunnicliff G, Raess BU, eds. GABA Mechanisms in Epilepsy. New York: Wiley-Liss; 1991:84104.

20. Edvinsson L, Krause DN. Pharmacological characterization of GABA receptors mediating vasodilation of verebral arteries in vitro. Brain Res. 1979:89-97.

21. Schwartz-Bloom RD, Miller KA, Evenson DA, Crain BJ, Nadler JV. Benzodiazepines protect hippocampal neurons from degeneration after transient cerebral ischemia: an ultrastructural study. Neuroscience. 2000;98(3):471-84.

22. Schwartz RD, Yu X, Katzman MR, Hayden-Hixson DM, Perry JM. Diazepam, given postischemia, protects selectively vulnerable neurons in the rat hippocampus and striatum. J Neurosci. 1995;15(1 Pt 2):529-39.

23. De Vente, J., Bol, J.G.J.M., Steinbusch, H.W.M.,. Localization of cGMP in the cerebellum of the adult rat: an immunocytochemical study. Brain Res. 1989;504: 332-337. 


\section{CHAPTER 2}

\section{Diazepam reduces brain lesion size in a photothrombotic model of focal ischemia in rats}

L.A.M. Aerden, A.G.H. Kessels, B.P.F. Rutten, J. Lodder, H.W.M. Steinbusch

Adapted from: Neurosci Lett. 2004 Aug 26;367(1):76-8. 


\begin{abstract}
The neuroprotective effect of diazepam has been demonstrated in global ischemia models in vivo and in vitro [Neuroscience (2000) 471]. We studied the effect of diazepam on lesion volume in a photothrombotic model of focal brain ischemia in the rat, and the relation of such effect to time of drug administration. For this purpose we induced photochemically a focal brain lesion, and added diazepam 10 $\mathrm{mg} / \mathrm{kg}$ intraperitoneally just before, at 1 and 4 hours after lesion induction. After 24 hours the rats were decapitated, and lesion volumes of 27 diazepam-treated rats were compared with that of 12 controls. Treated animals had a significant smaller lesion volume than controls, except those who received diazepam before induction of the lesion. We conclude that diazepam is neuroprotective in focal brain ischemia even when administered up to 4 hours after ischemia onset.
\end{abstract}




\section{Introduction}

During focal brain ischemia, disruption of the energy supply leads to massive cell depolarisation resulting in a quick rise in extracellular glutamate, which leads to the formation of free radicals, mitochondrial damage and disruption of cellular DNA $[2,14]$. Brain ischemia also leads to an increase of extracellular GABA-levels within minutes [4]. Theoretically, such increase might counteract the consequences of the glutamate release because of a GABA-mediated repolarisation of the post-synaptic membrane [11]. However, under ischemic conditions the affinity of the GABA receptor is decreased, and therefore the most rational strategy to increase GABAergic activity would be to increase the receptor's affinity for GABA [1]. Diazepam has such potential activity, by allosteric enhancement of the receptor [12]. Furthermore, diazepam lowers cell metabolism resulting in a decreased build-up of toxic by-products of anaerobic glycolysis [6]. It also increases cerebral blood flow in the penumbra through vasodilatation of unoccluded collateral vessels [3]. Therefore, diazepam is a promising neuroprotective drug. Its neuroprotective effect has been demonstrated in global ischemia models in vivo and in vitro [13]. Human stroke, however, is due to focal ischemia. A retrospective analysis suggested a potential neuroprotective effect of benzodiazepines in human stroke [8]. A clinical trial is in progress assessing the neuroprotective effect of diazepam in stroke: Early GABAergic Activation Study in Stroke (EGASIS) [10]. We studied the effect of diazepam on lesion volume in a photothrombotic model of focal brain ischemia in the rat. The primary question of our study was whether the administration of diazepam in the first 4 hours after the onset of focal ischemia resulted in a smaller lesion size in our rat model. The secondary question was whether such effect would depend on the time point of diazepam administration. 
Figure 1. Coronal cut through the hippocampus region illustrating an example of a photothrombotic lesion in the left hemisphere of a rat brain, maximum diameter of the lesion is $0,5 \mathrm{~mm}$. No difference is seen between treated or untreated animals. Abbreviation: $\mathrm{I}=$ ischemic lesion.

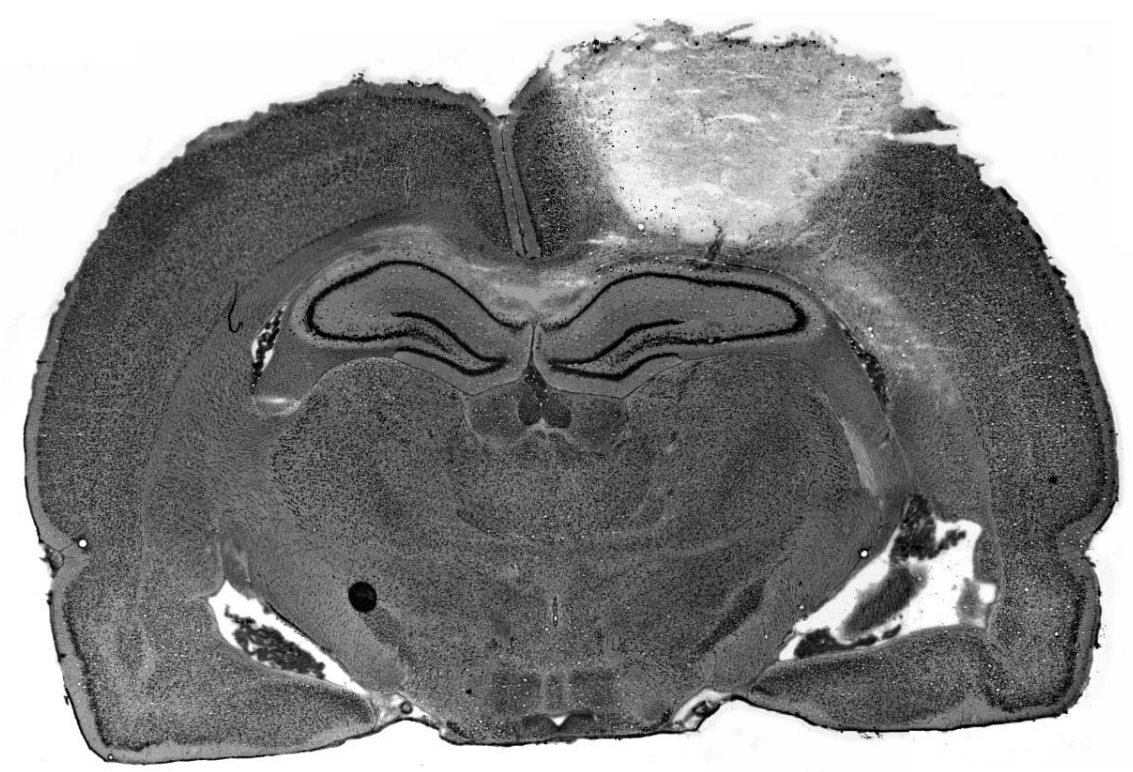




\section{Experimental procedure}

We used male Lewis rats of 10-12 weeks old, weighing between 210 and 320 grams, who had water and food at lib. Two rats received only Bengal rose i.v. without subsequent illumination, and two rats received only illumination without administering Bengal rose. These animals showed no brain lesion. Forty-two animals were divided at random in four treatment groups. Three rats died due to complications of narcosis or operative treatment. Twelve rats received no diazepam at all (no sham injections), eight received $10 \mathrm{mg} / \mathrm{kg}$ directly prior to surgery but after anaesthesia, ten received the same dose at one hour, and nine rats at four hours after surgery and the start of illumination. Diazepam was given in a single bolus dose intraperitoneally. Tracheal intubation was performed after administration of $4 \%$ halothane in a mixture of $70 \% \mathrm{~N}_{2} \mathrm{O}$ and $30 \% \mathrm{O}_{2}$ via a mask. After intubation, halothane concentration was reduced to $1 \%$ and artificial ventilation was started with a ventilation rate of $65 / \mathrm{min}$ and a tidal volume of $51 \mathrm{cc}$. Then the skull was placed in horizontal position and fixed, while the rats laid on a heating pad at $37{ }^{\circ} \mathrm{C}$. Rectal temperature was measured every 5 minutes, but was not regulated. An incision of $1.5 \mathrm{~cm}$ was made longitudinal over the scalp, and muscle and periost were removed. Rose Bengal $(7.5 \mathrm{mg} / \mathrm{ml}$ in $0.9 \% \mathrm{NaCl})$ was infused via the penisvene over $2 \mathrm{~min}$ utes $(0.133 \mathrm{ml} / 100$ gram body weight, final concentration $10 \mathrm{mg} / \mathrm{kg})$. After completing the infusion illumination was started with a fibre-optic light source. No special filters were used. Intensity at the end of the fibre was maintained at 25 klux using a light intensity meter (Janssen Scientific Instruments). The fibre was placed in a stereotactically controlled cylindrical mount containing a 1-mm diaphragm at its base. This was placed over the rat's right hemisphere $2.5 \mathrm{~mm}$ lateral of the central suture and $1.5 \mathrm{~mm}$ rostral from Illumination lasted 20 minutes. After the procedure the wound was sutured. Halothane was discontinued whereafter the animals resumed spontaneous respiration without thermal support. After 24 hours the animals were decapitated, brains were quickly removed, put in an aluminium box and frozen in acetone on dry-ice $\left(-30^{\circ} \mathrm{C}\right)$. Ten minutes later the brains were stored in a $-80^{\circ} \mathrm{C}$ freezer. Coronal sections were cut at $-20^{\circ} \mathrm{C}$ using a Leica Instruments cryostat. Sections were mounted on pregelatinized glass microslides, slice thickness was $50 \mu \mathrm{m}$. Every section was mounted serially, and every fourth section was stained with May-Grunwald-Giemsa for volume determination resulting in an interslice distance of $200 \mu \mathrm{m}$. Using an Olympus AX-70 microscope at a magnification of 20x, assisted by computer digital planimetry (AnalySIS), lesion volume was calculated using all Giemsa stained sections. Lesions appeared sharply demarcated (figure 1), and were easily identified by two independent investigators who were blinded for treatment type. Lesions were measured as relative values in comparison to the whole field under study on the screen, at the same magnification. All lesion areas were summed and multiplicated with the front to front interslice distance. Our hypothesis that diazepam is neuroprotective in this model was tested hierarchically. First, by comparing the lesion size in the control group with that of all diazepamtreated animals, using a t-test. When this resulted in a statistically significant difference, the hypothesis that the mean volume in the control group equals the mean volume in the different treatment groups was tested. 


\section{Results}

Univariate analyses of the differences in lesion volume between controls and the different treatment groups showed no statistical significance. However, there was a strong correlation $(\mathrm{r}=-0.54 ; \mathrm{p}<0.01)$ between animal weight and lesion size, i.e. lighter animals had larger lesions, whereas weight was unevenly distributed over the treatment groups: mean weights of controls was 281 gram, and 298, 280 and 276 gram in the different diazepam groups (see also figure 2). Therefore, we additionally performed a multivariate regression analysis with weight as an interval and time as a categorical covariable. This analysis showed that diazepam-treated animals had a significantly smaller lesion volume than controls $(p=0.03)$ (table 1$)$. When we compared different treatment groups separately, there was no difference between the animals that received diazepam before lesion induction and controls. Animals that received diazepam after one $(p=0.03)$, and after 4 hours $(p=0.04)$, had a significant smaller lesion than controls. The overall difference between treated animals and controls might be explained by an effect only in the animals that received treatment following lesion induction. However, the difference between lesion size in these groups just missed statistical significance $(p=0.08)$. One animal in the control group showed a massive brain lesion with a size far out of range compared with that in the other animals (figure 2), with a standardised residual after linear regression of 3.6; no explanation was found for this finding. Leaving this animal out of our analysis did not influence significance.

Figure 2. Distribution of photothrombotic lesion size and rat weight (in grams) in different treatment groups.

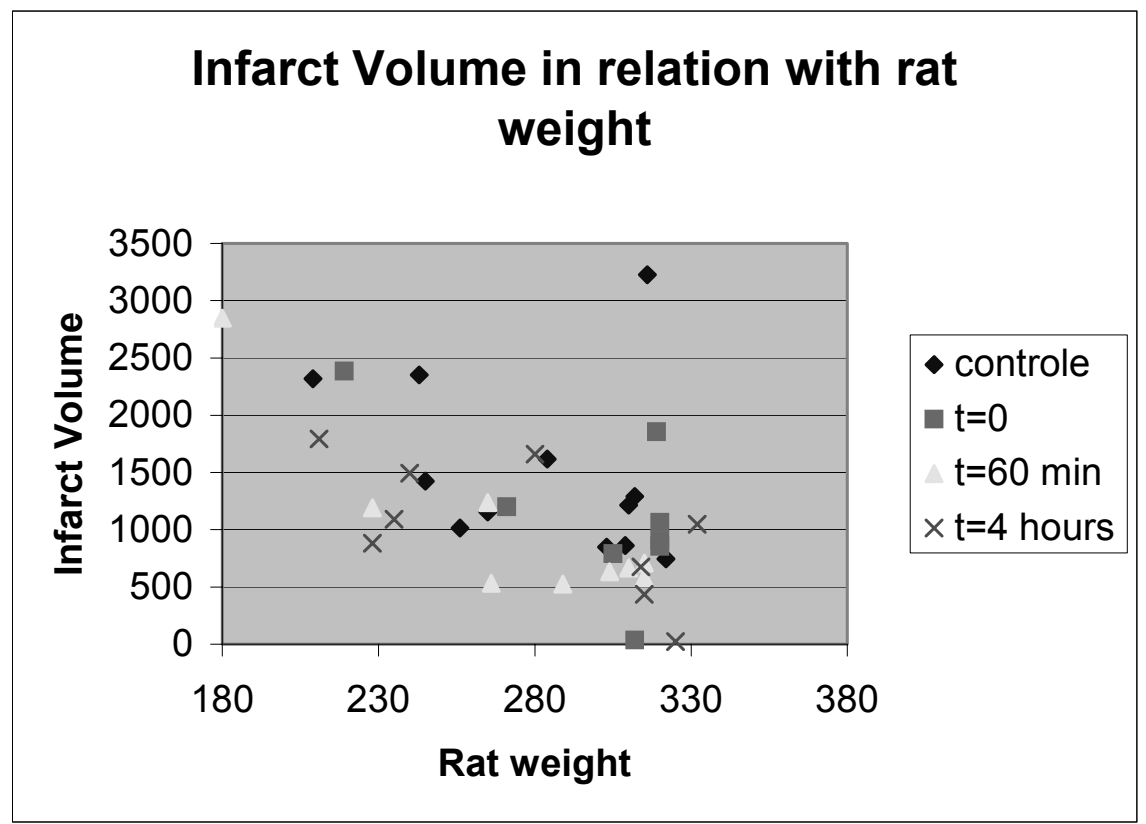


Table 1. Statistical analysis

\begin{tabular}{llll}
\hline Description (time $\mathrm{t}$ in minutes) & $\begin{array}{c}\text { Multivariate difference } \\
\text { in lesion size }[95 \% \mathrm{CI}]\end{array}$ & Multivariate P-value & Univariate P-value \\
\hline Diazepam total vs. controls & $-448[-852$ to -44$]$ & 0.03 & 0.05 \\
Diazepam $\mathrm{t}=0$ vs. controls & $-202[-740$ to 336$]$ & 0.45 & 0.29 \\
Diazepam $\mathrm{t}=60$ vs. controls & $-550[-1049$ to -51$]$ & 0.03 & 0.10 \\
Diazepam $\mathrm{t}=240$ vs. controls & $-549[-1064$ to -35$]$ & 0.04 & 0.12 \\
Diazepam $\mathrm{t}=0$ vs. diazepam $\mathrm{t}>0$ & $-373[-786$ to 40$]$ & 0.08 & 0.60 \\
\hline
\end{tabular}

\section{Discussion}

We found a clear effect of diazepam treatment on lesion size: animals that received diazepam had smaller lesions than controls. This neuroprotective effect of diazepam might be due to its GABA-ergic effect inhibiting cell depolarisation, lowering cell metabolism and increasing blood flow in the penumbra as has been demonstrated in global brain ischemia [7]. Surprisingly, neuroprotection was only evident when diazepam was given after the induction of the lesion. Diazepam passes easily through the blood-brain barrier, and high levels in the spinal fluid can be demonstrated within one hour [5]. After that, doses fall quickly to a stable level. This suggests that diazepam has an inhibiting effect somewhat more downstream the excitotoxic cascade, which could indicate that the protective effects of diazepam are not just the result of GABA-ergic inhibition of glutamate release, a blocking effect on the NMDA receptor, or a direct effect on calcium-influx. As NO production starts after 20 minutes and reaches its maximum after four hours in focal brain ischemia [9], an appealing explanation for the neuroprotective effect of diazepam is that it inhibits neuronal NOS directly in focal brain ischemia [4]. Further experiments to clarify the neuroprotective effects of diazepam are needed. If our findings could be extrapolated to human stroke, diazepam treatment offers a rational strategy for neuroprotection in acute stroke, with a possible time window of therapeutic opportunity of several hours. Such treatment could also be useful to prolong the time window for trombolysis.

\section{Conclusions}

Diazepam given one and four hours after, but not before the onset of focal brain ischemia in this rat model results in smaller lesion volumes at 24 hours. 


\section{References}

1. Akaike N, Inomata N, Tokutomi N. Contribution of chloride shifts to the fade of gammaaminobutyric acid-gated currents in frog dorsal root ganglion cells. J Physiol. 1987 Oct: 219-34.

2. Benveniste H, Drejer J, Schousboe A, Diemer NH. Elevation of the extracellular concentrations of glutamate and aspartate in rat hippocampus during transient cerebral ischemia monitored by intracerebral microdialysis. J Neurochem. 1984 Nov: 1369-74.

3. Edvinsson L, Krause DN. Pharmacological characterization of GABA receptors mediating vasodilation of verebral arteries in vitro. Brain Res. 1979 Sep: 89-97.

4. Globus MY, Busto R, Dietrich WD, Martinez E, Valdes I, Ginsberg MD. Effect of ischemia on the in vivo release of striatal dopamine, glutamate, and gamma-aminobutyric acid studied by intracerebral microdialysis. J Neurochem. 1988 Nov:1455-64.

5. Hironaka T, Fuchino K, Fujii T. Absorption of diazepam and its transfer through the blood-brain barrier after intraperitoneal administration in the rat. J Pharmacol Exp Ther. 1984 Jun: 809-15.

6. Kelly PA, McCulloch J. Effects of the putative GABAergic agonists, muscimol and THIP, upon local cerebral glucose utilisation J Neurochem. 1982 Sep: 613-24.

7. Lyden PD. GABA and neuroprotection. Int Rev Neurobiol. 1997: 233-58.

8. Lodder J, Heuts-van Raak L, Kessels F. GABA-ergic stimulation by benzodiazepines at stroke onset may ameliorate functional outcome in cardioembolic stroke patients. Cerebrovasc. Dis. 1996: 118 .

9. Malinski T, Bailey F, Zhang ZG, Chopp M. Nitric oxide measured by a porphyrinic microsensor in rat brain after transient middle cerebral artery occlusion. J Cereb Blood Flow Metab. 1993 May: 355-8.

10. van Raak L, Hilton A, Kessels F, Lodder J. Implementing the EGASIS trial, an international multicenter acute intervention trial in stroke. Control Clin Trials. 2002 Feb: 74-9.

11. Roberts E. Disinhibition as an organizing principle in the nervous system. The role of gammaaminobutyric acid. Adv Neurol. 1974:127-43.

12. Rudolph U, Crestani F, Benke D, Brunig I, Benson JA, Fritschy JM, Martin JR, Bluethmann H, Mohler H. Benzodiazepine actions mediated by specific gamma-aminobutyric acid(A) receptor subtypes. Nature. 1999 Oct 21: 796-800.

13. Schwartz-Bloom RD, Miller KA, Evenson DA, Crain BJ, Nadler JV. Benzodiazepines protect hippocampal neurons from degeneration after transient cerebral ischemia: an ultrastructural study. Neuroscience. 2000: 471-84.

14. Zhang ZG, Chopp M, Bailey F, Malinski T. Nitric oxide changes in the rat brain after transient middle cerebral artery occlusion. J Neurol Sci. 1995 Jan: 22-7. 


\section{CHAPTER 3}

\section{Dual effect of diazepam on cGMP levels in rat brain slices}

L.A.M. Aerden, H.W.M. Steinbusch, M. Markerink-van Ittersum,

J. Lodder, J. de Vente

Neurochem Res. 2004 Sep;29(9):1725-9. 


\begin{abstract}
The effect of diazepam on NO-mediated cGMP synthesis was studied in rat brain slices. It was found that diazepam dose-dependently decreased cGMP synthesis in cerebellar slices, with an inhibition of $90 \%$ at $1 \mathrm{mM}$ diazepam. cGMP levels in the presence of diazepam were not restored to control levels by the addition of $0.1 \mathrm{mM}$ sodium nitroprusside, whereas the decrease in cerebellar cGMP levels induced by $0.1 \mathrm{mM}$ L-NAME was restored by the simultaneous application of NO-donors. In addition to the decrease of cGMP levels in neuronal structures induced by $1 \mathrm{mM}$ diazepam, we observed increased cGMP immunoreactivity in glial cells in the cerebellum, the hippocampus, and the cerebral cortex. The significance of this observation is discussed.
\end{abstract}




\section{Introduction}

Benzodiazepines have a sedative and anxiolytic effect in humans. Drugs belonging to this class, diazepam being the most well known, have been prescribed since the 1960s. Recently, a number of new potential therapeutic indications have been reported. Thus, evidence was presented indicating that diazepam might have a neuroprotective effect after brain ischemia or trauma [1,2]. Diazepam is a gamma aminobutyric acid (GABA)-ergic drug that enhances the GABA-receptor, increasing $\mathrm{Cl}^{-}$ influx and thus stabilising the cell membrane. It prevents depolarisation of the presynaptical as well as the postsynaptic cell, thus acting as a functional glutamate antagonist. Presynaptically released glutamate can lead to an increase in intracellular $\mathrm{Ca}^{2+}$ in the postsynaptic cell [3], in some cells resulting in activation of neuronal nitric oxide synthase (NOS) and the synthesis of NO $[4,5,6]$. NO is a small molecule that passes easily through cell membranes and is an activator of soluble guanylyl cyclase (sGC) to produce cGMP $[7,8,9]$.

The purpose of our study was to determine if diazepam decreases NO-mediated cGMP levels in rat brain tissue. In the cerebellum, glutamate-induced NO levels and, subsequently, the cGMP levels, are high compared to other brain regions [10]. Therefore, we initially studied the effect of diazepam on cGMP levels in rat cerebellar tissue slices, using cGMP-immunocytochemistry. This technique not only permits the localisation of cGMP containing cells, but can also be used in a quantitative way [11]. In addition we studied the effects of diazepam on cGMP levels in cerebral cortex and hippocampus in slices of rat brain.

\section{Experimental Procedure}

Nineteen male Lewis rats (6-10 weeks old) were used. Animals were decapitated, the brains were removed as quickly as possible and immediately put into ice-cold oxygenated $\left(95 \% \mathrm{O}_{2} / 5 \% \mathrm{CO}_{2}\right)$ Krebs buffer $(121.1 \mathrm{mM} \mathrm{NaCl} ; 1.87 \mathrm{mM} \mathrm{KCl} ; 1.17$ $\mathrm{mM} \mathrm{KH} \mathrm{PO}_{4} ; 1.15 \mathrm{mM} \mathrm{MgSO}_{4} ; 24.9 \mathrm{mM} \mathrm{NaHCO} 3 ; 2.00 \mathrm{mM} \mathrm{CaCl}$; $11.0 \mathrm{mM}$ glucose). Brain slices $\left(400 \mu \mathrm{m}\right.$ thick) were cut using a Vibroslicer ${ }^{\circledR}$ (Campden Instruments, Sileby, Leicestershire, UK), while submerged in the same ice-cold buffer. Slices were transferred to a multiwell steady flow superfusion device containing 12 wells (Lohmann equipment, Castrop-Rauxel, Germany). They were superfused with the same buffer initially at room temperature and slowly warmed to $35{ }^{\circ} \mathrm{C}$ in the presence or absence of drugs at a flow rate of $2 \mathrm{ml} / \mathrm{min}$. IBMX was used as a non-specific phosphodiesterase (PDE) inhibitor. If present, 3-isobutyl-1methylxanthine (IBMX) $(1 \mathrm{mM})$, bicuculline $(0.1 \mathrm{mM})$, and diazepam (in different concentrations as indicated in "Results") were included from the start of the superfusion. The highest concentration of diazepam ( $1 \mathrm{mM})$, was near the saturation point of the solution. In some experiments, there was a yellow precipitate, probably due to benzoate [12], which means that the actual concentration of diazepam was possibly somewhat lower in this saturated solutions. Sodium nitroprusside (SNP) or diethylamine-NONOate (DEANO) was used as a NO-donor at a concentration of 0.1 $\mathrm{mM}$. These compounds were present during the last 10 minutes of the superfusion. Total superfusion time was 40 minutes. Slices were fixed in 4\% freshly depolymer- 
ised paraformaldehyde in $0.1 \mathrm{M}$ phosphatebuffer ( $\mathrm{pH}$ 7.4) containing $10 \%$ sucrose. Slices were embedded in Tissue-Tek and quickly frozen using $\mathrm{CO}_{2}$. Sections of 10 $\mu \mathrm{m}$ thick were cut using a cryostat. Visualisation of cGMP was performed using a primary sheep anti-cGMP-antibody (1:4000), and a secondary fluorescent donkey anti-sheep Alexa antibody (1: 100). cGMP-immunofluorescence was evaluated in slices from the cerebellum, the hippocampus and the frontal cortex. The specificity studies on the cGMP antiserum have been published [13]. Slices were examined using an Olympus AX-70 microscope (Tokyo, Japan) with epifluorescence illumination. Fluorescence intensity was recorded using a SONY power HAD CCD camera (Tokyo, Japan), and intensity values were converted into 265 grey values (265 highest intensity). Quantitative analysis was done using the analySIS ${ }^{\circledR}$ software package (Soft Imaging Systems, Gmbh, Münster, Germany). In order to compare slices of different experiments, relative values of fluorescence were determined for all conditions in relation to the fluorescence in the slice without diazepam $(100 \%)$, in the molecular layer as well as the white matter and granule cell layer.

\section{Results}

Intense cGMP-immunofluorescence was observed in the molecular layer of the cerebellar sections when slices had been incubated under basal conditions (Krebs + $1 \mathrm{mM}$ IBMX). In the granule cell layer and white matter, cGMPimmunofluorescence was less intense and more variable. Purkinje cells did not show any cGMP-immunofluorescence (Figs. 1a and 1b). Incubation of the slices in the presence of different doses of diazepam resulted in a dose-dependent decrease in cGMP-immunofluorescence in the molecular layer and granular layer of the cerebellum (Fig.1b). At the highest dose of $1 \mathrm{mM}$ diazepam, some highly fluorescent glial cells were observed along and in the white matter tracts and almost no cGMP-immunofluorescence was visualised in the surrounding tissue. These glial cells were characterised as astrocytes (Figs.1c and 1d.). By comparison, incubation of the cerebellar slices in the presence of $0.1 \mathrm{mM} \mathrm{N} \mathrm{G}^{\mathrm{G}}$-nitro-L-arginine methylester (L-NAME) resulted also in the loss of cGMP-immunoreactivity from the molecular and granule cell layer, however, under this condition, there was never any cGMPimmunostaining observed in astrocytes as shown in Fig. 1c, and cGMPimmunofluorescence could not be restored by adding an NO-donor (not shown, but see Ref. 18). Addition of $0.1 \mathrm{mM}$ SNP or $0.1 \mathrm{mM}$ DEANO to slices in which cGMP levels were depressed by $1 \mathrm{mM}$ diazepam did not result in a significant increase in the spread or intensity of the cGMP-immunofluorescence. This contrasts with the findings in slices incubated in the presence of L-NAME, where addition of NO-donors to the incubation medium resulted in the reappearance of cGMPimmunostaining. Quantification of the cGMP-immunofluorescence intensity using the analy(SIS) software system showed a decrease of $90 \%$ at the highest diazepam concentration. We observed a similar effect in the molecular and the granule cell layer. Adding a GABA receptor type A (GABAA)-antagonist, bicuculline, did not interfere with the effect of diazepam on cGMP fluorescence. 
Figure 1: cGMP-immunoreactivity in rat cerebellar slices incubated in vitro. (a) Basal conditions (see "Experimental Procedure"), (b-c) in the presence of $1 \mathrm{mM}$ diazepam, (d) GFAP immunostaining of the same area as shown in (c), showing the double labelling of astrocytes marked with an arrowhead. Abbreviations: $\mathrm{G}=$ granular layer, $\mathrm{M}=$ molecular layer, $\mathrm{W}=$ White matter, and $\mathrm{P}=$ Purkinje cells.
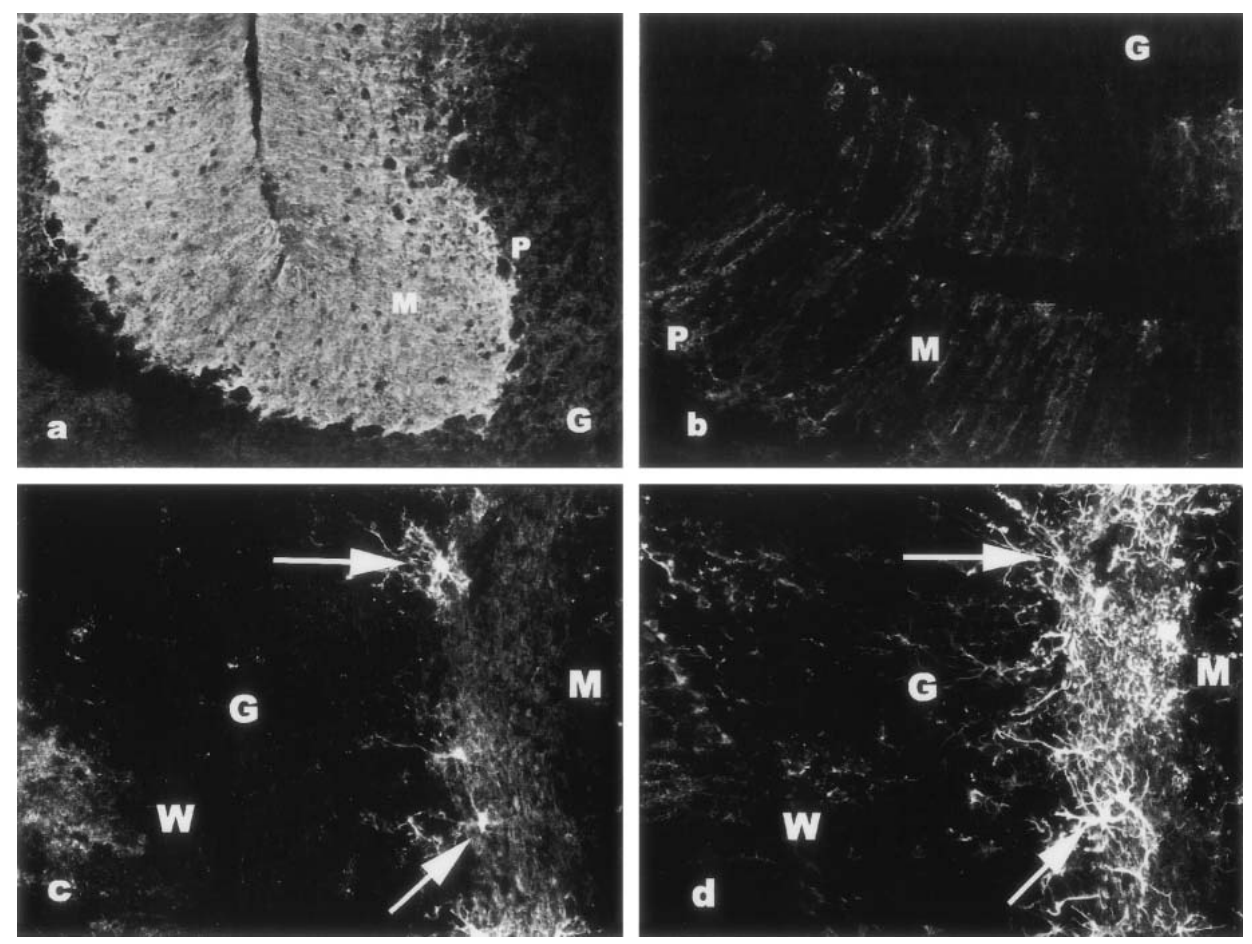
Figure 2: cGMP-immunoreactivity in rat cerebral cortex and hippocampus slices incubated in vitro. (a) Cortex, in the presence of $1 \mathrm{mM}$ diazepam, (b) cortex, basal conditions (see "Experimental Procedure"), (c) hippocampus, in the presence of 1 mM diazepam. (d) detail of part (c).
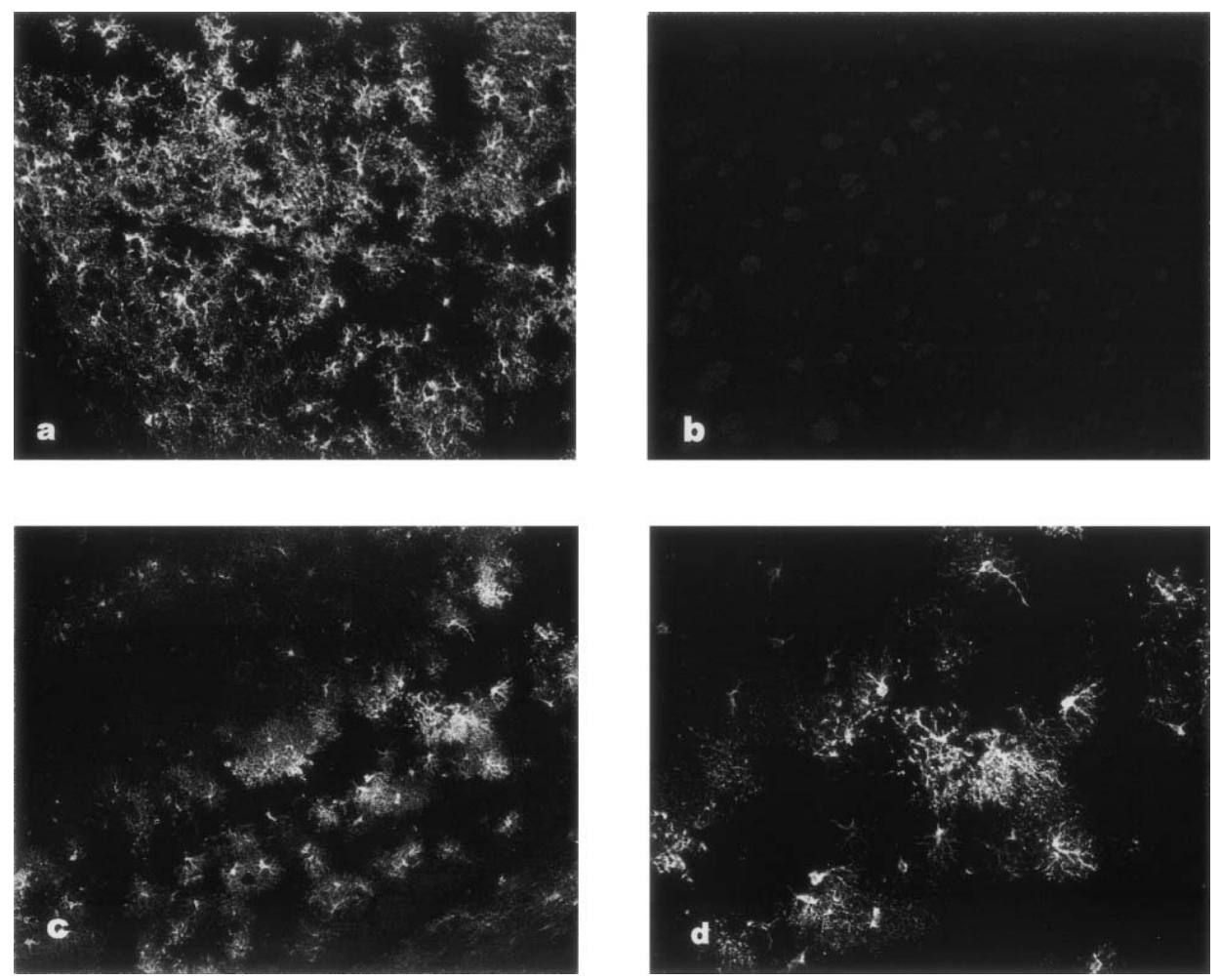
In the area of the stratum lacunosum molecular of the hippocampus, some cGMPimmunostaining is always observed in varicose fibres, when hippocampus slices are incubated in the presence of $1 \mathrm{mM}$ IBMX. This basal cGMP-immunoreactivity was not observed in sections from slices that had been incubated in the presence of 1 $\mathrm{mM}$ diazepam. On the other hand, incubation in the presence of diazepam resulted in the appearance of immunostaining in glial cells throughout the hippocampus (Figs. 2c and 2d). Similarly, incubation of cortical tissue slices in the presence of diazepam also resulted in the appearance of cGMP-immunoreactivity in glial cells (Figs. 2a and 2b).

\section{Discussion}

It has been known for a long time that cGMP levels in the cerebellum are about one order of magnitude larger than in other areas of the central nervous system [10]. cGMP synthesis in the cerebellum has been observed in the molecular layer in parallel fibres, Bergmann glial cells, stellate cells and basket cells, and in the granule cell layer in astrocytes and granule cells [14,15,16,17]. No cGMP-immunoreactivity has been demonstrated in the Purkinje cells $[16,18]$. In tissue sections from cerebellar slices incubated in vitro, an intense cGMP-immunostaining is present. In addition, cGMP formation in the cerebellum is dependent on NO-synthesis $[6,19,20]$. Therefore, we studied the effect of diazepam on NO synthesis using rat cerebellar slices incubated in vitro.

Surprisingly, the addition of diazepam in the incubation medium resulted in a dual effect on cGMP-immunofluorescence in the cerebellar slices. First, there was a strong decrease in cGMP-immunofluorescence in the molecular and granule cell layers. This was an expected result, as it had been demonstrated already by Biggio [21] that diazepam decreases cGMP levels in the rat brain. The failure of bicuclline to block this effect indicates that not the well-known GABA-ergic effects of diazepam, but mechanisms somewhat later in the signalling cascade play a role in this effect on cGMP. As it is known that cGMP-synthesis in the cerebellum is largely glutamate dependent [6,22], this suggests that the addition of diazepam in the incubation medium inhibits the glutamate neurotransmission in the cerebellar slice, resulting in decreased NO-synthesis and subsequently decreased cGMP levels. The fact that cGMP-immunofluorescence does not increase after addition of an NOdonor to the incubation medium leads to the conclusion that diazepam inhibits the formation of cGMP at the level of soluble guanylate cyclase, independent from the extracellular NO-concentration.

Secondly, in slices that had been incubated in the presence of diazepam, we observed intense cGMP-immunostaining in astrocytes in the white matter tracts of the cerebellum, in the hippocampus, and in the cerebral cortex (other areas were not studied). This observation is reminiscent to the effect of rolipram on cGMP levels in hippocampal astrocytes [11]. Rolipram is a highly selective inhibitor of the cAMP-specific PDE-4 [23]. Addition of rolipram to hippocampal slices incubated in vitro resulted in a similar appearance of cGMP-immunoreactive astrocytes [11]. Similarly, incubation of cerebellar slices in the presence of $0.1 \mathrm{mM}$ rolipram increased cGMP levels in the slices significantly when assessed with image analysis, 
and strong cGMP-immunoreactivity was observed in the same locations as when slices had been incubated in the presence of diazepam. Recently, diazepam has been reported to possess PDE-4 inhibiting properties [24]. The family of PDEs is complex, and regulation of PDE activity by either cAMP or cGMP has recently been described [25]. Although the high concentration of diazepam used in these experiments could result in inhibition of other PDEs [26], it might also be argued that non-specific effects would rather result in a visualisation of cGMPimmunoreactivity like found after incubation of the slice in the presence of IBMX, a known non-specific inhibitor of PDE-activity (see Fig. 1a). Nevertheless, it remains unknown how inhibition of PDE-4 by rolipram or diazepam results in an increase of cGMP levels in astrocytes [26].

In conclusion, diazepam inhibits soluble guanylate cyclase, thus inhibiting directly the formation of cGMP independent from the concentration of NO, and has an effect, possible on PDE-4, which increases cGMP in astrocytes, although NO synthesis is at the same time severely limited by this compound. As diazepam has a clear effect on cGMP-levels in the brain, further clinical and laboratory investigations should be performed to reveal a neuroprotective effect of this well known drug. 


\section{References}

1. Dowden, J., Reid, C., Dooley, P., et al. 1999. Diazepam-induced neuroprotection: dissociating the effects of hypothermia following global ischemia. Brain Res. 829:1-6.

2. Schwartz-Bloom, R.D., Miller, K.A., Evenson, D.A., Crain, B.J., Nadler, J.V., 2000. Benzodiazepines protect hippocampal neurons from degeneration after transient cerebral ischemia: an ultrastructural study. Neuroscience 98: 471-84.

3. Boulton, C.L., Southam, E., Garthwaite,J,.1995.Nitricoxide dependent longterm potentiation is blocked by a specific inhibitor of soluble guanylyl cyclase. Neuroscience 69: 699-703.

4. Bredt, D.S., Snyder, S.H., 1989. Nitric oxide mediates glutamate-linked enhancement of cGMP levels in the cerebellum. Proc. Natl. Acad. Sci. USA 86: 9030-9033.

5. Knowles, R.G., Palacios, M., Palmer, R.M.J., Moncada, S., 1989. Formation of nitric oxide from L-arginine in the central nervous system: a transduction mechanism for stimulation of the soluble guanylate cyclase. Proc. Natl. Acad. Sci. USA 86: 5159-5162.

6. Garthwaite, J., 1991. Glutamate, nitric oxide and cell-cell signalling in the nervous system. Trends in Neurosci. 14: 60-67.

7. Ignarro, L.J., 1989. Heme-dependent activation of soluble guanylate cyclase by nitric oxide: regulation of enzyme activity by porphyrins and metalloporphyrins. Semin. Hematol. 26: 63-76.

8. Murad, F., 1994. Regulation of cytosolic guanylyl cyclase by nitric oxide: the NO-cyclic GMP signal transduction system. Adv. Pharmacol. 26: 19-33.

9. Schmidt, H.H.H.W., 1992. NO, CO and OH. Endogenous soluble guanylyl cyclase-activating factors. FEBS Lett. 307: 102-107.

10. Ferrendelli, J.A., 1978. Distribution and regulation of cyclic GMP in the central nervous system. Adv. Cyclic Nucleotide Res. 9: 453-464.

11. Van Staveren, W.C.G., Markerink-van Ittersum, M., Steinbusch, H.W.M., De Vente, J. 2001. The effects of phosphodiesterase inhibition on cyclic GMP and cyclic AMP accumulation in the hippocampus of the rat. Brain Res. 888: 275-286.

12. Dam, M. and Christiansen, J. 1976. Diazepam: intravenous infusion in the treatment of status epilepticus. J. Acta. Neurol. Scand. 54:278-80.

13. Tanaka, J., Markerink-van Ittersum, M., Steinbusch, H.W.M., De Vente, J., 1997. Nitric oxidemediated cGMP synthesis in oligodendrocytes in the developing rat brain. Glia 19: 286-97.

14. De Vente, J., Bol, J.G.J.M., Steinbusch, H.W.M., 1989. Localization of cGMP in the cerebellum of the adult rat: an immunocytochemical study. Brain Res. 504: 332-337.

15. De Vente, J., Hopkins, D.A., Markerink-van Ittersum, M., Emson, P.C., Schmidt, H.H.H.W., Steinbusch, H.W.M., 1998. Distribution of nitric oxide synthase and nitric oxide-receptive, cyclic GMP-producing structures in the rat brain. Neuroscience 87: 207-241.

16. Southam, E., Morris, R., Garthwaite, J., 1992. Sources and targets of nitric oxide in rat cerebellum. Neurosci. Lett. 137: 241-244.

17. Southam, E., Garthwaite, J., 1993. The nitric oxide-cyclic GMP signalling pathway in rat brain. Neuropharmacology 32: 1267-1277. 
18. De Vente, J., Steinbusch, H.W.M., 2000. Nitric oxide- cGMP signaling in the rat brain. In: Handbook of Chemical Neuroanatomy, Volume 17: Functional Neuroanatomy of the Nitric Oxide System. H.W.M. Steinbusch, J. de Vente, S.R. Vincent, eds. Elsevier, pp. 355-415.

19. De Vente, J., Bol, J.G.J.M., Berkelmans, H.S., Schipper, J., Steinbusch, H.W.M., 1990. Immunocytochemistry of cGMP in the cerebellum of the immature, adult, and aged rat: the involvement of nitric oxide. A micropharmacological study. Eur. J. Neurosci. 2: 845-862.

20. Garthwaite, J., Garthwaite, G., 1987. Cellular origins of cyclic GMP responses to excitatory amino acid receptor agonists in rat cerebellum in vitro. J. Neurochem. 48: 29-39.

21. Biggio, G., Brodie, B.B., Costa, E., Guidotti, A., 1977. Mechanisms by which diazepam, muscimol, and other drugs change the content of cGMP in cerebellar cortex. Proc. Natl. Acad. Sci. USA 74: 3592-3596.

22. Garthwaite, J., Charles, S.L., Chess-Williams, R., 1988. Endothelium-derived relaxing factor release on activation of NMDA receptors suggests role as intercellular messenger in the brain. Nature 336: 385-388.

23. Conti, M., Jin, S.L.C., 2000. The molecular biology of cyclic nucleotide phoshodiesterases. Progr. Nucl. Acid Res. 63: 1-38.

24. Collado, M.C., Beleta, J., Martinez, E., et al 1998. Functional and biochemical evidence for diazepam as a cyclic nucleotide phosphodiesterase type 4 inhibitor. Br. J. Pharmacol. 123: 1047-54.

25. Soderling, S.H., Beavo, J.A., 2000. Regulation of cAMP and cGMP signaling: new phosphodiesterases and new functions. Curr. Opinion Cell Biol. 12: 174-179.

26. Bellamy, T.C., Garthwaite, J., 2001. "cAMP-specific" phosphodiesterase contributes to cGMP degradation in cerebellar cells exposed to nitric oxide. Mol. Pharmacol. 59: 54-61. 


\section{CHAPTER 4}

\section{Validation of the Oxfordshire Community Stroke Project syndrome diagnosis derived from a standard symptom list in acute stroke}

Leo Aerden, Gert-Jan Luijckx, Stefano Ricci, Anne Hilton, Fons Kessels, Jan Lodder

J Neurol Sci. 2004 May 15;220(1-2):55-8. 


\begin{abstract}
Background: The Oxfordshire Community Stroke Project (OCSP) classification allows distinction of stroke subtypes with different prognosis. OCSP classification inferred from clinical signs filled out on patient entry forms has been used to facilitate subgroup analysis in clinical trials. However, such procedure has not been validated against clinical diagnosis. In preparation for an acute stroke trial, we set out to perform such a validation. Methods: An OCSP syndrome diagnosis of 194 acute stroke patients in four hospitals was made within $24 \mathrm{~h}$ using a standard list with neurological signs, to be filled out by a stroke physician or neurological resident on duty. This was compared with OCSP diagnosis within 2 days of stroke onset by a (blinded) stroke neurologist ('gold standard'). Results: The proportion of the OCSP syndromes was quite similar between standard list and clinical judgement. Sensitivity, specificity, positive and negative predictive values were respectively: LACS: 0.76, 0.88, 0.72, 0.90; TACS: 0.63, 0.93, 0.62, 0.88; PACS: 0.62, 0.76, 0.63, 0.75; POCS: $0.50,0.98,0.60,0.97$. Kappa for agreement was 0.63 (LACS), 0.37 (PACS), 0.50 (TACS). Neuro-imaging falsified stroke subtype diagnosis in 40 cases $(20.6 \%)$ diagnosed using the standard list, and $42(21.6 \%)$ diagnosed by stroke neurologists. Conclusion: A standard list-derived stroke syndrome diagnosis may be used as a clinical test to make an OCSP syndrome diagnosis in acute stroke. The use of such list in acute stroke trials may facilitate uniformity in early stroke subtype diagnosis. However, to increase such uniformity, ancillary methods such as acute MRI should be evaluated.
\end{abstract}




\section{Introduction}

Stroke is a heterogeneous disease, both in underlying cause and clinical presentation. Efficacy of potential neuroprotective treatment may relate to differences in prognosis between patient subgroups. Therefore, in acute stroke intervention trials it is rational to distinguish between subgroups that relate to prognosis. Such a distinction should be valid, accurate and easy, without being time consuming. The Oxfordshire Community Stroke Project (OCSP) classification offers such a possibility [1]. Using a limited number of neurological signs, it distinguishes four ischemic stroke syndromes, which have a different prognosis with respect to case fatality, stroke recurrence and disability [2-7]. The classification has a fair to good inter-observer reliability $[8,9]$, shows good correlation with lesion site and size on imaging [1013], and also with the degree of ultrasound-detected intracranial arterial lesions [14]. Besides the practical convenience, which is a major advantage in acute stroke trials, no ancillary investigations are required to classify the patient, so that the loss of valuable time is kept to a minimum. Several published acute stroke trials use(d) the OCSP classification, mainly to perform subgroup analysis [15-18]. This demonstrates the acceptance of the classification for such analyses. Several ongoing trials also use this classification to that end $[19,20]$. However, a syndrome diagnosis could not be noted in the case record forms, but was inferred from an acute stroke scale [17] or from a standard signs and symptoms list noted before randomisation $[15,16]$. Although the last method seems most reliable, its value in comparison to an OCSP diagnosis made by a neurologist has not been determined. Whilst preparing an acute stroke trial, we performed such a comparison.

\section{Patients and methods}

Patients were included between October 1998 and April 2000 by the neurological department in four hospitals: University Hospital Maastricht (99), Servizio per le Malattie Cerebrovascolari Perugia (15), Maasland Hospital Sittard (38), Atrium Hospital Heerlen (42). They were admitted and examined within $24 \mathrm{~h}$ following stroke onset. Patients with coma were excluded, as were those who were completely functionally dependent before stroke, because functional improvement beyond this prior state is unlikely to be achieved by any acute stroke therapy. After history taking and physical examination, and prior to $\mathrm{CT}$, the neurological resident or the stroke physician (in Perugia only) on duty filled out a standard list (see addendum). When neurological signs and symptoms had stabilised, but at least within 2 days after stroke onset, a neurologist with a special interest in cerebrovascular diseases, and who was blinded for the earlier listing and results of ancillary investigations including those of neuro-imaging, made a syndrome diagnosis according to the OCSP criteria. Patients who on clinical grounds likely had a cerebral bleeding were not included; (e.g. patients who were comatose from stroke onset). CT or MRI was assessed for the type of stroke (intra-cerebral haemorrhage, lacunar or territorial brain infarct) by experts blinded to the clinical information and only knew that the patient had suffered a stroke. We inferred the four syndromes from the standard list 
data by use of the following algorithm: LACS was defined as all syndromes with a paresis or sensory loss in more than one ipsilateral body region, or unilateral ataxia alone, but always without aphasia, neglect or visual impairment. POCS was defined as: definite brain stem signs, or homonymous hemianopia, but always without aphasia, neglect or other higher 'cortical functions'. TACS was defined as: homonymous hemianopia, and neglect or aphasia, together with paresis of the ipsilateral limbs. Every syndrome that did not fit into one of these three syndrome algorithms was a PACS. If a sign could not be assessed, it was marked as maximal deficit for that sign. Sensitivity, specificity, positive and negative predictive values of the standard list-derived syndrome diagnosis were calculated with the diagnosis of the neurologists as 'gold standard'. CT or MRI was performed in all patients, mainly to confirm a stroke diagnosis. Our study aim was not to validate the OCSP classification (the syndrome diagnosis made by the neurologist), and therefore no specific time schedule for neuro-imaging was enforced. Consequently, CT or MRI findings could contradict and not always confirm the clinical diagnosis; a single, early CT often shows no specific abnormalities, and not all patients had MRI. We also calculated the concordance between list-derived and experts' diagnosis using kappa statistics.

\section{Results}

Out of 201 patients, seven were true positive intracerebral haemorrhages (ICH) according to experts' clinical syndrome diagnosis, and were consequently not included in the testing of the validity of the standard list for ischemic stroke subtype diagnosis. The remaining 194 patients included one false positive and eight false negative ICHs made by expert diagnosis compared with CT/MRI. These nine were included in the final analysis. There were 111 males and 83 females. Median age was 71 years, range: 49-91 years. All patients had CT within 1 week after stroke onset; 18 had repeated CT and28 MRI. Table 1 shows the numbers of OCSP syndromes as derived from the list and from experts' clinical judgement. Figures are quite similar between the groups, but do not reveal differences on an individual patient level.

Table 1 OCSP syndromes; comparison between standard list-derived and expert diagnosis in 194 acute stroke patients (percentages between parentheses)

\begin{tabular}{lrrrr}
\hline Syndrome & \multicolumn{2}{c}{ Symptom list } & \multicolumn{2}{c}{ Clinicians } \\
\hline & & & & \\
LACS & 56 & $(29)$ & 55 & $(29)$ \\
TACS & 49 & $(25)$ & 49 & $(25)$ \\
PACS & 79 & $(41)$ & 78 & $(40)$ \\
POCS & 10 & $(5)$ & 12 & $(6)$ \\
Total & & & & \\
\end{tabular}


Table 2. Cross tabulation of standard list-derived and expert clinical syndrome diagnosis in 194 patients

\begin{tabular}{|c|c|c|c|c|c|}
\hline \multirow[t]{2}{*}{ List } & \multicolumn{5}{|c|}{ Experts } \\
\hline & LACS & TACS & PACS & POCS & TOTAL ( list) \\
\hline LACS & 41 & 1 & 13 & 1 & 56 \\
\hline TACS & 1 & 31 & 14 & 3 & 49 \\
\hline PACS & 11 & 17 & 49 & 2 & 79 \\
\hline POCS & 2 & - & 2 & 6 & 10 \\
\hline TOTAL (experts) & 55 & 49 & 78 & 12 & 194 \\
\hline
\end{tabular}

Table 2 shows the cross tabulation for individual patients between the list-derived diagnosis and that of the experts. PACI was the most frequent dissenting diagnosis in LACI and TACI categories. Table 3 shows the sensitivity, specificity, positive and negative predictive values (with 95\% confidence interval) of the standard list as a diagnostic test when compared with the OCSP diagnosis of the clinicians. Overall, the list-derived diagnosis correlates fairly well with the clinical diagnosis. However, the expert diagnosis was not infallible: neuro-imaging falsified their diagnosis in 42 $(21.6 \%)$ of the 194 cases. This figure was similar to that for the standard list: 40 (20.6\%) of 194. Kappa for TACS diagnosis was $0.50,0.37$ for PACS, and 0.63 for LACS. The low number of POCS did not allow a reliable kappa estimate.

Table 3. Comparison between standard list-derived and experts' clinical diagnosis as gold standard $(\mathrm{PPV}=$ positive predictive value, $\mathrm{NPV}=$ negative predictive value; (95\% confidence intervals between parentheses)

\begin{tabular}{lllll}
\hline Syndrome & PPV & NPV & Sensitivity & Specificity \\
\hline & & & & \\
LACS & $0.75(0.64-0.86)$ & $0.89(0.81-0.97)$ & $0.73(0.61-0.85)$ & $0.88(0.79-0.97)$ \\
TACS & $0.63(0.49-0.77)$ & $0.88(0.79-0.97)$ & $0.63(0.49-0.77)$ & $0.88(0.79-0.97)$ \\
PACS & $0.63(0.52-0.74)$ & $0.74(0.64-0.84)$ & $0.62(0.51-0.73)$ & $0.75(0.65-0.86)$ \\
POCS & $0.60(0.32-0.88)$ & $0.97(0.87-1.07)$ & $0.50(0.22-0.78)$ & $0.98(0.90-1.06)$
\end{tabular}




\section{Discussion}

Our data show that the standard list of neurological signs scored acceptably well as a clinical test to predict expert clinical syndrome diagnosis. Concordance expressed by kappa was 'fair' for PACS, and 'substantial' for LACS and TACS. Variation in the degree of concordance may be related to small numbers, especially in the POCI group. Discrepancies between the list-derived diagnosis and that of the clinician may relate to a possible change in symptoms between early assessment and expert clinical scoring. OCSP assessment may be problematic in critically ill patients. However, such patients may not benefit from a potential neuroprotective drug, and are likely excluded from most acute intervention trials, so that this potential problem may be small in such trials. It should be noted that the OCSP syndrome diagnosis was targeted at ischemic stroke, whereas distinction between brain infarct and haemorrhage can only reliably be made with the aid of CT or MRI. Therefore, we excluded the gold standard's true positive ICHs, but included false positive and false negative ICH diagnosis. In cases where the list-derived and expert diagnosis did not concur, the list was not necessarily wrong, as the clinical diagnosis was also not infallible: in about $20 \%$ it was falsified by neuro-imaging findings, which was similar to that of the symptom list. However, our study was not meant to validate symptom list and expert clinical diagnosis against neuro-imaging, in which case well planned MRI and patient follow-up should have been used as 'gold standard' for both. The participating centres differed in the number of patients they included, as is often also the case in clinical trials. Clinical diagnosing may be better in some centres than in others, but our relatively small patient sample did not allow reliable estimates comparing centres. If in an acute stroke trial randomisation is based on stroke subtype, accurate diagnosis of subtypes is required in order not to 'dilute' any effectiveness of an acute therapy by false inclusion of other stroke subtypes. Also, false exclusion of target patients may render trial logistics less effective, and may even create bias in patient selection. Acute MRI, including diffusion MRI, would be ideal for targeting patients for acute stroke intervention trials. With additional perfusion MRI, even patients with a potentially salvageable penumbra may be selected. However, the validity of these techniques as selection procedure to include patients into acute stroke trials, has not sufficiently been established. Most series were small, which may point at some difficulty recruiting most stroke patients into such MRI studies. If diffusion/perfusion MRI is employed in acute stroke trials, one should be aware of increase in treatment delay, which may in turn lower the chance of detecting treatment efficacy. However, postrandomisation MRI may be valuable in post-hoc subclassification, as in large trials treatment will likely be distributed equally within such subgroups, whereas such sub-classification will be highly reliable. Considering the approximately $20 \%$ falsely classified cases in our study, stratification of patients in an acute

stroke trial using a stroke severity scale may be preferred over the OCSP classification, but such scales may not allow differentiation between prognostically important stroke subtypes. Furthermore, stroke scales are not linear, and some symptoms may underrate or overstress the 
importance of stroke severity as outcome predictor. Also, there is no consensus on what stroke severity scale based stroke categories are particularly valid with respect to outcome. As lesion classification by eventual neuro-imaging will not replace patient characterisation at the time of randomisation, a clinical scoring system remains mandatory to allow pre-defined subgroup analyses in acute stroke trials. Although the OCSP classification does not differentiate stroke subtypes based on underlying cause, it at least does so for lacunar strokes, which is prognostically relevant [21]. Our data show that standard listing of neurological signs on early stroke patient assessment has an acceptable validity when compared with expert clinical diagnosis for different stroke subtypes identified by OCSP syndrome diagnosis. It offers an acceptable alternative as long as sophisticated imaging modalities are not yet sufficiently validated and available to be used in large acute stroke trials. We cannot conclude from our data that a standard list is better or worse than clinical sub-typing of stroke patients, but its use may make acute stroke syndrome diagnosis to be used in subgroup analyses in acute stroke trials more uniform. However, to increase such uniformity, ancillary methods such as acute MRI, should be evaluated.

\section{Acknowledgements}

The "profilerings Fonds" of the University Hospital Maastricht is gratefully acknowledged for financial support, and dr. Bruno Bruni, divisione Medicina, Citta'della Pieve Hospital, Italy, for his cooperation. 


\section{References}

1. Bamford J, Sandercock P, Dennis M, Burn J, Warlow C. Classification and natural history of clinically identifiable subtypes of cerebral infarction. Lancet 1991;337:1521-6.

2. Bamford J, Sandercock P, Dennis M, Warlow C, Jones L, McPherson K, et al. A prospective study of acute cerebrovascular disease in the community: the Oxfordshire Community Stroke Project 1981-86: 1. Methodology, demography and incident cases of first-ever stroke. J Neurol Neurosurg Psychiatry 1988;51:1373- 80.

3. Bamford J, Sandercock P, Dennis M, Burn J, Warlow C. A prospective study of acute cerebrovascular disease in the community: theOxfordshire Community Stroke Project-1981-86. Incidence, case fatality rates and overall outcome at one year of cerebral infarction, primary intracerebral and subarachnoid haemorrhage. J Neurol NeurosurgPsychiatry 1990;53:16 - 22.

4. Bamford J, Dennis M, Sandercock P, Burn J, Warlow C. The frequency, causes and timing of death within 30 days of a first stroke: the Oxfordshire Community Stroke Project. J Neurol Neurosurg Psychiatry 1990;53:824-9.

5. Pinto AN, Melo TP, Lourenco ME, Leandro MJ, Brazio A, Carvalho L, et al. Can a clinical classification of stroke predict complications and treatments during hospitalisation? Cerebrovasc Dis 1998;8:204-9.

6. Anderson CS, Taylor BV, Hankey GJ, Stewart-Wynne EG, Jamrozik KD. Validation of a clinical classification for subtypes of acute cerebral infarction. J Neurol Neurosurg Psychiatry 1994;57:1173- 9 .

7. Wardlaw JM, Dennis MS, Lindley RI, Sellar RJ, Warlow CP. The validity of a simple clinical classification of acute ischaemic stroke. J Neurol 1996;243:274-9.

8. Dewey H, MacDonell R, Donnan G, Freema E, Thrift A, Sharples C. Inter-rater reliability of stroke sub-type classification by neurologists and nurses within a community-based stroke incidence study. J Clin

Neurosci 2001;8:14- 7 .

9. Lindley RI, Warlow CP, Wardlaw JM, Dennis MS, Slattery J, Sandercock PA. Interobserver reliability of a clinical classification of acute cerebral infarction. Stroke 1993;24:1801-4.

10. Lindgren A, Norrving B, Rudling O, Johansson BB. Comparison of clinical and neuroradiological findings in first-ever stroke. A population- based study. Stroke 1994;25:1371- 7 .

11. Mead GE, Lewis SC, Wardlaw JM, Dennis MS, Warlow CP. How well does the Oxfordshire community stroke project classification predict the site and size of the infarct on brain imaging? J Neurol Neurosurg Psychiatry 2000;68:558-62.

12. Sharma JC, Hasson MS, Butcher C. How well does the Oxfordshire Community Stroke Project classification predict the site and size of infarct of brain imaging? J Neurol Neurosurg Psychiatry 2001;70: 567.

13. Tei H, Uchiyama S, Koshimizu K, Kobayashi M, Ohara K. Correlation between symptomatic, radiological and etiological diagnosis in acute ischemic stroke. Acta Neurol Scand 1999;99:1925 .

14. Mead GE, Wardlaw JM, Dennis MS, Lewis SC, Warlow CP. Relationship between pattern of intracranial artery abnormalities on transcranial doppler and Oxfordshire Community Stroke Project clinical classification of ischemic stroke. Stroke 2000;31:714-9. 
15. International Stroke Trial Collaborative Group. The International Stroke Trial (IST): a randomised trial of aspirin, subcutaneous heparin, both, or neither among 19435 patients with acute ischaemic stroke. Lancet 1997;349:1569-81.

16. CAST (Chinese Acute Stroke Trial) Collaborative Group. CAST: randomised placebo-controlled trial of early aspirin use in 20,000 patients with acute ischaemic stroke. Lancet 1997;349:1641 9.

17. Wahlgren NG, Ranasinha KW, Rosolacci T, Franke CL, van Erven PM, Ashwood T, et al. Clomethiazole acute stroke study (CLASS): results of a randomized, controlled trial of Clomethiazole versus placebo in 1360 acute stroke patients. Stroke 1999;30:21-8.

18. Lyden PD, Ashwood T, Claesson L, Odergen T, Friday GH, Martin- Munley S. The Clomethiazole Acute Stroke Study in Ischemic, Hemorrhagic, and t-PA Treated Stroke: design of a phase III trial in the United States and Canada. J Stroke Cerebrovasc Dis 1998;7:435 - 41.

19. Bradford A, Lees K. Design of the Intravenous Magnesium Efficacy in Acute Stroke (IMAGES) trial. Curr Control Trials, Cardiovasc Med 2000;1:184- 90.

20. van Raak L, Hilton A, Kessels F, Lodder J. Implementing the EGASIS trial, an international multicenter acute intervention trial in stroke. Control Clin Trials 2002;23:1-6.

21. De Jong G, van Raak L, Kessels F, Lodder J. Stroke subtype and mortality, a follow-up study in 998 patients with cerebral infarct. J Clin Epidemiol 2003;56:262-8. 


\section{Addendum}

\section{Standard list of neurological signs}

Yes No Can't assess

Body side affected left right

Definite brain stem signs

Unilateral weakness (and/or sensory deficit) affecting face

Unilateral weakness (and/or sensory deficit) affecting arm/hand

Unilateral weakness (and/or sensory deficit) affecting leg/foot

Ataxia (out of proportion to any weakness) affecting arm and/or leg

Dysarthria

Dysphasia

Homonymous visual field defect

Neglect / spatial disorder / apraxia / agnosia (and/or)

Other deficit:

Is the patient fully alert? 


\section{CHAPTER 5}

\section{Diazepam in acute stroke; any harm? A randomized, double-blind, placebo- controlled safety study in 865 patients from the EGASIS (Early GABA-ergic Activation Study In Stroke) trial}

L.A.M. Aerden, E.P.M. van Raak, A.M. Hilton, E.L.M. Hardy, A.G.H.

Kessels, J. Lodder; on behalf of the EGASIS Study Group 


\begin{abstract}
Introduction: - In the 2005 AHA/ASA-Endorsed Practice Guidelines for the management of adult stroke rehabilitation was stated that diazepam or other benzodiazepines are not recommended during the stroke recovery period because of possible deleterious effects on recovery [7]. The evidence level for this statement was of level D. Controlled data could raise the evidence level and strengthen eventual recommendations, which would be of significant practical value. In the double-blind, placebo-controlled, EGASIS trial we tested the effect on functional outcome at three months, and safety, of an early three-day diazepam treatment in almost 900 acute stroke patients. We here report on the potential harm of such drug regimen, based on the detailed safety data of that trial.

Methods: - Patients were included within 12 hours after stroke onset and were randomly assigned to treatment with diazepam $10 \mathrm{mg}$, twice daily for three days or placebo. Results: Safety analyses were performed on 865 stroke patients. Baseline characteristics were well balanced between treatment groups. There were significantly fewer recurrent strokes among diazepam treated infarct patients. Paradoxical reactions and urinary tract infections were significantly less frequent in diazepam treated ICH patients, whereas pneumonia occurred significantly more often in this group. Conclusions: - Our study is the first randomised, double-blind, placebocontrolled trial on the safety of early diazepam treatment in acute stroke patients. Our data on safety indicate that early treatment with diazepam for whatever reason in acute ischemic stroke is at least safe.
\end{abstract}




\section{Introduction}

Recovery from stroke may in part depend upon brain plasticity that is modulated by the central GABA system [1]. Enhancement of the GABA-ergic activity results in a down-regulation of this process, which can consequently impede functional recovery. Animal studies have indeed demonstrated such effect, and even short-term administration of a GABA-agonist such as diazepam, lead to a more protracted functional recovery in a rat model of brain ischemia [2]. Ziemann et al. demonstrated in healthy subjects that an increase of GABA activity by the benzodiazepine lorazepam depressed cortical plasticity, which was assessed by trans-cranial magnetic stimulation in a biceps muscle practice model [3]. Goldstein et al. found in an adjusted analysis a significant higher degree of upper-extremity motor impairment and a lower degree of independence in activity of daily living in 37 patients who received 'detrimental' drugs than in 59 with 'neutral' drugs in the Sygen in Acute Stroke Study [4]. Twenty-eight percent of patients in that study received a benzodiazepine. Effects for this drug group were not analysed separately because of small numbers, instead it was included in the 'detrimental' drugs group. In the observational study of Troisi et al., almost 19 percent of 154 stroke patients received a benzodiazepine following stroke onset and during a two-month rehabilitation period [5]. Analysed together with other patients on 'detrimental' drugs, these patients did worse on two-month outcome, which was measured using the Barthel Index and Rivermead Mobility Index. Lazar et al. found that administration of the benzodiazepine midazolam to eight stroke patients one week after stroke onset, evoked temporal re-emergence of improved neurological signs [6]. These data lead the 2005 AHA/ASA-Endorsed Practice Guidelines for the management of adult stroke rehabilitation care to conclude: 'diazepam or other benzodiazepines are not recommended during the stroke recovery period because of possible deleterious effects on recovery' [7]. The evidence level for this statement, however, was of level D, which implied 'a recommendation that a procedure may be considered not useful/effective or may be harmful'. Controlled data could raise the evidence level and strengthen eventual recommendations, which would be of significant practical value considering the proportion of stroke patients that already use a benzodiazepine during stroke onset or receive one shortly after that. In the double-blind placebo-controlled EGASIS trial we tested the efficacy on functional outcome at three months and safety of an early three-day diazepam treatment in almost 900 acute stroke patients [8]. We here report on the potential harm of such drug regimen, based on the detailed safety data of that trial. 


\section{Patients and methods}

For detailed description of the methods we refer to our earlier paper [8].

Adult males and females were included within 12 hours after stroke onset. For stroke confirmation and subtyping, CT or MRI within 7 days was mandatory. Patients with a clear indication for or contraindication to benzodiazepines (at the discretion of the attending physician) were excluded, as were patients with unresponsive coma. Patients were randomised centrally by a 24-hour telephone randomisation service using a computer-generated random listing of the two treatment assignments (diazepam $10 \mathrm{mg}$, twice daily for three days or placebo) blocked in groups of four and stratified for centre, time from stroke onset to start of treatment (three strata: $<3,3-6,6-12$ hours) and whether the patient was fully alert or not. All involved (patients, investigators, treating physicians, nurses, etc), except our hospital's pharmacist, were blinded for trial medication. Baseline characteristics were recorded: age, gender, time between stroke onset and randomisation, neurological status including alertness, clinical neurological deficit, pulse and blood pressure, potential cardiac source of embolism, and vascular risk factors (diabetes mellitus, hypertension, ischemic heart disease and prior stroke). As a measure of stroke severity we used the Oxfordshire Community Stroke Project classification validated for clinical trial use [9, Chapter four of this thesis].

For safety analysis all 'Serious Adverse Events' were recorded. Also all potential treatment side effects, whether they were serious or not, were collected on the Case Record Form (CRF) at two weeks or earlier discharge; these were: paradoxical reactions (agitation, confusion) requiring treatment; respiratory depression requiring (oxygen) therapy; a drop in blood pressure requiring treatment; deep venous thrombosis; pulmonary embolism; systemic arterial embolus; pneumonia, urinary tract infection, or sepsis requiring treatment with antibiotics; a serious fall; recurrent stroke; ECG- or enzyme-confirmed myocardial infarction. We considered that any direct adverse effect would likely to become manifest within the first two weeks, whereas eventual longer lasting detrimental effects would be reflected in the threemonth outcome measurements. All adverse events within two weeks were compared between treatment groups using odds ratios (OR). Separate analyses were performed for all stroke patients, for infarct patients and for patients with intracerebral haemorrhage (ICH). These analyses were performed univariately, using the Pearson chi-square test or Fisher 's exact test if appropriate. 


\section{Results}

Due to the expiry of the trial medication rectioles, patient inclusion was prematurely stopped when 880 patients had been randomised. One patient had been included twice; the second inclusion was abandoned. Six patients $(0.7 \%)$ had no stroke (three had a tumour, one Todd's paralysis, one peripheral paresis, and one pneumonia that aggravated pre-existing neurological deficit). Of the remaining 873 stroke patients $(442=50.6 \%$ on diazepam), eight patients $(0.9 \%$; three on diazepam) were lost to follow-up at two weeks. Therefore, safety analyses were performed on 865 stroke patients $(439=50.8 \%$ on diazepam). Baseline characteristics were well balanced between treatment groups (table 1a), also within each stroke class (table 1b).

Table 1A. Baseline Characteristics for all stroke patients

\begin{tabular}{lcl}
\hline & \multicolumn{3}{c}{ Stroke patients (N=865) } \\
\cline { 2 - 4 } Characteristics, n (\%) & Diazepam (N=439) & Placebo (N=426) \\
\hline Age ( mean \pm SD) & $70.45 \pm 12.02$ & $70.46 \pm 11.96$ \\
Age ( range) & $72.44(20.97-96.91)$ & $72.62(20.68-95.51)$ \\
Male & $235(53.5 \%)$ & $241 \quad(56.6 \%)$ \\
Treatment start < 3 hours & $87(19.8 \%)$ & $78 \quad(18.3 \%)$ \\
Treatment start 3-6 hours & $185(42.1 \%)$ & $180 \quad(42.3 \%)$ \\
Treatment start 6-12 hours & $167(38.0 \%)$ & $168 \quad(39.4 \%)$ \\
Patient is alert & $385(87.7 \%)$ & $366 \quad(85.9 \%)$ \\
Cardioembolic mechanism & $109(24.8 \%)$ & $110 \quad(25.8 \%)$ \\
Diabetes Mellitus & $66(15.0 \%)$ & $74 \quad(17.4 \%)$ \\
Hypertension & $210(47.8 \%)$ & $202 \quad(47.4 \%)$ \\
Ischemic Heart Disease & $111(25.3 \%)$ & $122 \quad(28.6 \%)$ \\
Prior stroke & $90(20.5 \%)$ & $82 \quad(19.2 \%)$ \\
\hline
\end{tabular}


Table 1B. Baseline Characteristics for Infarct patients and ICH patients separately

\begin{tabular}{lllll}
\hline & \multicolumn{2}{c}{ Infarct patients (N=769) } & \multicolumn{2}{c}{ ICH patients (N=96) } \\
\cline { 2 - 6 } Characteristics, n (\%) & Diazepam (N=393) & Placebo (N=376) & Diazepam (N=46) & Placebo (N=50) \\
\hline & & & & \\
Age (mean \pm SD) & $70.34 \pm 12.03$ & $70.12 \pm 12.11$ & $71.37 \pm 12.03$ & $73.02 \pm 10.52$ \\
Age ( range) & $72.38(20.97-96.91)$ & $71.92(20.68-95.51)$ & $73.20(38.33-87.70)$ & $75.18(44.76-89.36)$ \\
Male & $203(51.7 \%)$ & $215(57.2 \%)$ & $32(69.6 \%)$ & $26(52.0 \%)$ \\
Treatment start <3 hours & $71(18.1 \%)$ & $64(17.0 \%)$ & $16(34.8 \%)$ & $14(28.0 \%)$ \\
Treatment start 3-6 hours & $173(44.0 \%)$ & $159(42.3 \%)$ & $12(26.1 \%)$ & $21(42.0 \%)$ \\
Treatment start 6-12 hours & $149(37.9 \%)$ & $153(40.7 \%)$ & $18(39.1 \%)$ & $15(30.0 \%)$ \\
Patient is alert & $350(89.1 \%)$ & $324(86.2 \%)$ & $35(76.1 \%)$ & $42(84.0 \%)$ \\
Cardioembolic mechanism & $104(26.5 \%)$ & $102(27.1 \%)$ & $5(10.9 \%)$ & $8(16.0 \%)$ \\
Diabetes Mellitus & $59(15.0 \%)$ & $69(18.4 \%)$ & $7(15.2 \%)$ & $5(10.0 \%)$ \\
Hypertension & $187(47.6 \%)$ & $180(47.9 \%)$ & $23(50.0 \%)$ & $22(44.0 \%)$ \\
Ischemic Heart Disease & $104(26.5 \%)$ & $118(31.4 \%)$ & $7(15.2 \%)$ & $4(8.0 \%)$ \\
Prior stroke & $83(21.1 \%)$ & $74(19.7 \%)$ & $7(15.2 \%)$ & $8(16.0 \%)$ \\
\hline
\end{tabular}

In 308 patients $(35.6 \% ; 156$ on diazepam) one or more potential treatment side effects were reported; in 26 patients (11 on diazepam) events were also reported as a Serious Adverse Event. Treatment was discontinued prematurely because of adverse events in 10 patients ( 6 on diazepam). Only two patients (one on diazepam) received the antidote flumazenil, both because of respiratory depression on day three. Tables $2 \mathrm{a}$ and $2 \mathrm{~b}$ present the two-week events in detail. Most events were evenly distributed between treatment groups within each stroke class. However, there were significantly fewer recurrent strokes among diazepam treated infarct patients. Paradoxical reactions and urinary tract infections were significantly less frequent in diazepam treated ICH patients, whereas pneumonia occurred significantly more often in this group. 
Table 2A. Adverse events within two weeks for all stroke patients

\begin{tabular}{|c|c|c|}
\hline \multirow[b]{2}{*}{ Characteristics, n (\%) } & \multicolumn{2}{|c|}{ Stroke patients $(\mathrm{N}=865)$} \\
\hline & Diazepam $(\mathrm{N}=439)$ & Placebo $(\mathrm{N}=426)$ \\
\hline Any event(s) & $156 \quad(35.5 \%)$ & $152 \quad(35.7 \%)$ \\
\hline Reported as serious & $11(2.5 \%)$ & $15 \quad(3.5 \%)$ \\
\hline Paradoxical reactions & $12(2.7 \%)$ & $14(3.3 \%)$ \\
\hline Respiratory depression & $43 \quad(9.8 \%)$ & $39(9.2 \%)$ \\
\hline Drop in blood pressure & $14(3.2 \%)$ & $11(2.6 \%)$ \\
\hline $\begin{array}{l}\text { Deep venous thrombosis or } \\
\text { Pulmonary embolism }\end{array}$ & $1 \quad(0.2 \%)$ & $3(0.7 \%)$ \\
\hline Systemic arterial embolus & $1(0.2 \%)$ & $0 \quad(0.0 \%)$ \\
\hline Pneumonia & $59 \quad(13.4 \%)$ & $63(14.8 \%)$ \\
\hline Urinary tract infection & $41 \quad(9.3 \%)$ & $44 \quad(10.3 \%)$ \\
\hline Sepsis & $7(1.6 \%)$ & $4 \quad(0.9 \%)$ \\
\hline Serious fall & $3(0.7 \%)$ & $2(0.5 \%)$ \\
\hline Recurrent stroke & $13(3.0 \%)^{*}$ & $25 \quad(5.9 \%)$ \\
\hline Myocardial infarction & $9(2.1 \%)$ & $6(1.4 \%)$ \\
\hline Death & $48 \quad(10.9 \%)$ & $50 \quad(11.7 \%)$ \\
\hline
\end{tabular}

$* \mathrm{OR}=0.49(0.25-0.97) ; \mathrm{P}=0.037$

Table 2B. Adverse events within two weeks for infarct patients and ICH patients separately

\begin{tabular}{|c|c|c|c|c|}
\hline \multirow[b]{2}{*}{ Characteristics, n (\%) } & \multicolumn{2}{|c|}{ Infarct patients $(\mathrm{N}=769)$} & \multicolumn{2}{|c|}{ ICH patients $(\mathrm{N}=96)$} \\
\hline & Diazepam (N=393) & Placebo $(\mathrm{N}=376)$ & Diazepam $(\mathrm{N}=46)$ & Placebo $(\mathrm{N}=50)$ \\
\hline Any event(s) & $132 \quad(33.6 \%)$ & $126(33.5 \%)$ & $24 \quad(52.2 \%)$ & $26(52.0 \%)$ \\
\hline Reported as serious & $9 \quad(2.3 \%)$ & $12(3.2 \%)$ & $2(4.3 \%)$ & $3(6.0 \%)$ \\
\hline Paradoxical reactions & $12(3.1 \%)$ & $8 \quad(2.1 \%)$ & $0(0.0 \%)^{*}$ & $6(12.0 \%)$ \\
\hline Respiratory depression & $35(8.9 \%)$ & $34(9.0 \%)$ & $8(17.4 \%)$ & $5(10.0 \%)$ \\
\hline Drop in blood pressure & $14(3.6 \%)$ & $11(2.9 \%)$ & $0 \quad(0.0 \%)$ & $0 \quad(0.0 \%)$ \\
\hline Deep venous thrombosis or & $1(0.3 \%)$ & $3(0.8 \%)$ & $0 \quad(0.0 \%)$ & $0 \quad(0.0 \%)$ \\
\hline Pulmonary embolism & & & & \\
\hline Systemic arterial embolus & $0 \quad(0.0 \%)$ & $0 \quad(0.0 \%)$ & $1 \quad(2.2 \%)$ & $0 \quad(0.0 \%)$ \\
\hline Pneumonia & $43 \quad(10.9 \%)$ & $58 \quad(15.4 \%)$ & $16(34.8 \%) \dagger$ & $5 \quad(10.0 \%)$ \\
\hline Urinary tract infection & $40 \quad(10.2 \%)$ & $33(8.8 \%)$ & $1(2.2 \%) \ddagger$ & $11(22.0 \%)$ \\
\hline Sepsis & $5(1.3 \%)$ & $4(1.1 \%)$ & $2(4.3 \%)$ & $0 \quad(0.0 \%)$ \\
\hline Serious fall & $2(0.5 \%)$ & $1 \quad(0.3 \%)$ & $1 \quad(2.2 \%)$ & $1 \quad(2.0 \%)$ \\
\hline Recurrent stroke & $11(2.8 \%) \S$ & $22 \quad(5.9 \%)$ & $2(4.3 \%)$ & $3(6.0 \%)$ \\
\hline Myocardial infarction & $8 \quad(2.0 \%)$ & $6(1.6 \%)$ & $1 \quad(2.2 \%)$ & $0 \quad(0.0 \%)$ \\
\hline Death & $38 \quad(9.7 \%)$ & $44(11.7 \%)$ & $10 \quad(21.7 \%)$ & $6 \quad(12.0 \%)$ \\
\hline
\end{tabular}

\footnotetext{
$* \mathrm{P}=0.027 ; \dagger \mathrm{OR}=4.80(1.59-14.50) ; \mathrm{P}=0.003 ; \ddagger \mathrm{OR}=0.08(0.01-0.64) ; \mathrm{P}=0.003 ; \S \mathrm{OR}=0.46(0.22-0.97) ; \mathrm{P}=0.037$
} 


\section{Discussion}

We found at least one of the defined potential treatment side effects in over onethird of our stroke patients. However, as diazepam and placebo treated patients did not differ in this respect, most of these 'side effects' should likely to be taken as regular complications of stroke. Also, the number of 'serious adverse events', premature treatment discontinuations, and the number of patients who needed the diazepam antidote flumazenil did not differ between the two treatment groups. However, when we analysed ischemic and haemorrhagic stroke patients separately, differences emerged. First of all, respiratory depression together with pneumonia, the most feared complications during the discussions we had with potential collaborators during the preparing phase of the trial, appeared rather lower (not statistically significant) in at least the diazepam treated infarct patients. In those with $\mathrm{ICH}$, however, pneumonia was registered significantly more often in the diazepam group. The statistically significant lower number of patients with urinary tract infections in this group may possibly relate to a more frequent use of antibiotics for pneumonia, but this remains speculative. Surprisingly, paradoxical reactions like confusion, were more prevalent in the placebo group, which may be due to chance alone. There were also more (not statistically significant) deaths among the diazepam treated ICH patients, which may in part relate to the higher number of patients with pneumonia. Also surprising was the lower (statistically significant) stroke recurrence rate in the diazepam treated infarct group. This may be a chance effect, but may also relate to the depressor effect of diazepam on the stroke related enhanced sympathetic activity, thereby lowering the chance of cardiac complications such as myocardial infarction or arrhythmia induced stroke recurrence.

Our data on 3-month outcome suggested benefit of the diazepam treatment, especially in the infarct group, and more likely even in patients with a cardioembolic stroke [8]. In any case, 3-month assessment in the infarct patients, but not in the ICH patients, did not suggest worse outcome related to the early use of diazepam. These data corroborate with our earlier findings from a large prospective observational study in infarct patients [10].

Whether higher drug dose or more protracted use would have different effects on the harm/benefit ratio remains speculative. A dose of $10 \mathrm{mg}$ diazepam twice daily for five days in a dose finding study prior to the trial, was found to be safe but not feasible to apply because of drowsiness that interfered with regular patient care starting around the fifth day, but we did not measure any long-term effects in that study [11]. In any case, our data sustain the idea that it is unnecessary to stop the use of a benzodiazepine when an ischemic stroke occurs. Not only is continuation for at least a few days without harm, it even may have a beneficial effect. Earlier we found that discontinuation may significantly increase the chance of provoking epileptic seizures with almost a factor ten [12]. The balance between beneficial and detrimental effects of benzodiazepine use following stroke may well depend on the dose used and the duration of treatment $[13,14$, Chapter three of this thesis). In a rat model of focal ischemia benefit of diazepam depended strongly on timing of the drug's administration [15, Chapter two of this thesis). We may add to these conditions the factor of stroke subtype. 
Our study is the first randomised, double-blind, placebo-controlled trial on the safety of early diazepam treatment in acute stroke patients, and although the trial was ended prematurely, our data on safety are solid and indicate that early treatment with diazepam for whatever reason in acute ischemic stroke is at least safe, which might be quite reassuring for both patient and doctor when a benzodiazepine is indicated in an individual ischemic stroke patient. Obviously, more data on the effects of long-term use of benzodiazepines following stroke are required before rational advice can be given on the use of such drugs with a practically relevant degree of certainty. Inferences from patho-physiological considerations or even from animal studies may be misleading 


\section{Appendix}

Members of the EGASIS Study Group (participating investigators who provided and cared for study patients, per country in alphabetical order):

Austria (39 patients): M. Brainin, Landesnervenklinik Maria Gugging, Maria Gugging; A. Doppelbauer, Landeskrankenhaus Oberwart, Oberwart.

Belgium (20 patients): M. Gille, Clinique St. Elisabeth, Brussels; A. Peeters, Cliniques Universitaires St Luc, Brussels.

Denmark (7 patients): G. Boysen, Bispebjerg Hospital, Copenhagen.

The Netherlands (679 patients): W.C. Baard, Vlietland Ziekenhuis, Schiedam; C. Bouwsma and A.W.F. Rutgers, Martini Ziekenhuis, Groningen; P.E. Briët, Diaconessenhuis, Leiden; P.J.A.M. Brouwers, Medisch Spectrum Twente, Enschede; S.F.T.M. de Bruijn, Ziekenhuis Leyenburg, Den Haag; J.A. Carpay, Ziekenhuis Gooi-Noord, Blaricum; P.H.M.F. Domburg, Laurentius Ziekenhuis, Roermond; C.L. Franke, Atrium Medisch Centrum, Heerlen; A.M.H.G. van der HeijdenMontfroy, Maasziekenhuis, Boxmeer; G. de Jong, Isala Klinieken, Zwolle; L.J. Kappelle, UMC Utrecht, Utrecht; K. Keizer, Catharina Ziekenhuis, Eindhoven; R.B. van Leeuwen and H.P. Bienfait, Gelre Ziekenhuizen, Apeldoorn; W.H.G. Lieuwens, Oosterschelde Ziekenhuis, Goes; J. Lodder, Academisch Ziekenhuis Maastricht, Maastricht; G.J. Luijckx, Maasland Ziekenhuis, Sittard; B.J. Meems, St. Maartens Gasthuis, Venlo; K. ten Napel, Scheperziekenhuis, Emmen; E. Oosterhoff, Medisch Centrum Molendael, Baarn; P.H.M. Pop, Sint Elisabeth Ziekenhuis, Venray; T.H. Sie, Rode Kruis Ziekenhuis, Beverwijk; J.S. Straver, Hofpoort Ziekenhuis, Woerden; J.Th.J. Tans, Medisch Centrum Haaglanden, Den Haag; Th.P.J. Timmerhuis, Carolus Ziekenhuis, 's Hertogenbosch; J.C.B. Verheij, Vlietland Ziekenhuis, Vlaardingen; M.S.G. van Zagten, Zuiderziekenhuis, Rotterdam.

Poland (135 patients): A. Czlonkowska and T. Mendel, Institute of Psychiatry and Neurology, Warsaw; L. Dobrzynska, Akademia Medyczna w Gdansku, Gdansk; W. Drozdowski, Medical Academy, Bialystok; K. Pierzchala, Silesian Medical Academy, Zabrze.

\section{The EGASIS safety and data monitoring committee:}

Professor Jan G.P. Tijssen (chairman), Department of Cardiology, Academic Medical Center - University of Amsterdam, Amsterdam, the Netherlands; Professor Charles P. Warlow, Department of Clinical Neurosciences, The University of Edinburgh, Western General Hospitals, Edinburgh, Scotland; and Professor Livia Candelise, Istituto di Clinica Neurologica, Università degli Studi di Milano, IRCCS Ospedale Policlinico, Milano, Italy. 


\section{References}

1. Johansson $B B$. Brain plasticity and stroke rehabilitation. The Willis Lecture. Stroke. 2000;31:223-230.

2. Goldstein LB. Influence of common drugs and related factors on stroke outcome. Curr Opinion Neurol. 1997;10:52-57.

3. Ziemann U, Muellbacher W, Hallett M, Cohen LG. Modulation of practice-dependent plasticity in human motor cortex. Brain 2001;124:1171-1181.

4. Goldstein LB; the Sygen in Acute Stroke Study Investigators. Common drugs may influence motor recovery after stroke. Neurology. 1995;45:865-871.

5. Troisi E, Paolucci S, Silvestrini M, Vernieri F, Grasso MG, Caltagirone C. Prognostic factors in stroke rehabilitation: the possible role of pharmacological treatment. Acta Neurol Scand. 2002;105:100-106.

6. Lazar RM, Fitzsimmons B-F, Marshall RS $<$ Berman MF, Bustillo MA, Young WL, Mohr JP, Shah J, Robinson JV. Reemergence of stroke deficits with midazolam challenge. Stroke. 2002;33:283-285.

7. Bates B, Choi JY, Duncan PW, Glasberg JJ, Graham GD, Katz RC, Lamberty K, Reker D, Zorowitz R.., AHA/ASA-Endorsed Practice Guidelines. Veterans Affairs/Department of Defense Clinical Practice Guideline for the management of adult stroke rehabilitation Care. Executive summary. Stroke. 2005;36:2049-2056.

8. Lodder J. van Raak L, Hilton A, Hardy E, Kessels A., on behalf of the EGASIS Study Group. Diazepam to improve acute stroke outcome: results of the early GABA-ergic activation study in stroke trial. A randomised double-blind placebo-controlled trial. Cerebrovasc Dis. 2006;21:120 127.

9. Aerden L, Luijckx GJ, Ricci S, Hilton A, Kessels F, Lodder J. Validation of the Oxfordshire Community Stroke Project (OCSP) syndrome diagnosis derived from a standard symptom list in acute stroke. J Neurol Sci. 2004;220:55-58. (Chapter four of this thesis).

10. Lodder J, Heuts-van Raak L, Kessels F. GABA-ergic stimulation by benzodiazepines at stroke onset may ameliorate functional outcome in cardioembolic stroke patients. Cerebrovasc Dis. 1996;6:118.

11. Lodder J, Luijckx GJ, van Raak L, Kessels F. Diazepam treatment to increase the cerebral GABA-ergic activity in acute stroke: A feasibility study in 104 patients. Cerebrovasc Dis. 2000;10:437-440.

12. Heuts-van Raak L. Seizure risk and peri-stroke medication use. Chapter 6 in: Seizures following a first cerebral infarct. Risk factors and prognosis. Academic dissertation, ISBN 90-9009220-X, University of Maastricht, 1996.

13. Goldstein LB. Potential effects of common drugs on stroke recovery. Arch Neurol. 1998;55:454456.

14. Aerden LAM, Steinbusch H, Markerink-van Ittersum M, Lodder J, de Vente J. Dual effect of diazepam on cGMP levels in rat brain slices. Neurochem Res. 2004;29:1725-1729. (Chapter three of this thesis). 
15. Aerden LAM, Kessels FAGH, Rutten BPF, Lodder J, Steinbusch HWM. Diazepam reduces brain lesion size in a photothrombotic model of focal ischemia in rats. Neurosci Lett. 2004;367:76-78. (Chapter two of this thesis). 


\title{
CHAPTER 6
}

\section{Common drugs in acute ischemic stroke and their influence on outcome. An observational study in 1013 stroke patients}

\author{
L.A.M Aerden, E.P.M. van Raak, A.M.H.P. Boreas, \\ A.G.H. Kessels, J. Lodder
}

Submitted 2006 


\begin{abstract}
Background: Various drugs when used during the acute phase of stroke may worsen stroke outcome, whereas on the other hand other drugs are potentially neuroprotective. Therefore, we studied the use of various drugs at stroke onset as independent predictors of functional outcome at three months. Methods: In an observational study of 1013 acute ischemic stroke patients, medication on admission was registered and divided in ten groups of commonly used drugs. Functional outcome at three months was rated, using the modified Rankin scale, as functional independent (Rankin 0, 1, and 2) or functional dependent or dead (Rankin 3, 4, and 5, or 6). Predictive value of medication use on outcome was analysed using multivariate regression analyses. Results: Vasodilator use was unfavourably associated with functional independence at three months in lacunar stroke (OR 0.37, 95\%CI 0.16$0.89 ; \mathrm{p}=0.025)$. The use of diuretics was unfavourably associated with functional independence in atherothrombotic stroke (OR 0.43, 95\% CI 0.22-0.82; $\mathrm{p}=0.010$ ). The use of calcium antagonists was independently associated with better outcome at three months in cardioembolic stroke (OR 2.64, 95\%CI 1.04-6.69; $p=0.042$ ). Conclusions: Considering the importance of blood pressure treatment following TIA or ischemic stroke, our observations may have clinical implications: Vasodilators and diuretics may better be avoided in patients with a high stroke risk, be it lacunar or large vessel infarction, whereas other drugs may be used without harm. Calcium antagonists on the other hand may exert benefit in patients with an increased risk for cardioembolic stroke, and may become drugs of first choice in those patients.
\end{abstract}




\section{Introduction}

Acute ischemic stroke is one of the major causes of death and disability in the western world, especially amongst the elderly [1]. Medication use increases with age, and 85 percent of the elderly over 75 years of age use one or more drugs [2]. Various drugs when used during the acute phase of stroke may worsen stroke outcome, whereas on the other hand some other drugs are potentially neuroprotective [3]. The arguments pro or con the use of certain drugs during the acute stroke phase mainly stem from theoretical considerations and animal experiments, whereas clinical evidence is scarce. Therefore, in an observational study of 1013 acute ischemic stroke patients we studied the use of various drugs at stroke onset as independent predictors of functional outcome at three months.

\section{Patients and methods}

Between July 1987 and June 1992, 815 consecutive patients, and between September 1998 and August 1999, 236 consecutive patients with a first ever symptomatic supratentorial brain infarct had been registered in the Maastricht Stroke Registry (MSR) [4]. During these two periods medication at stroke onset was meticulously registered in a study on post-stroke epilepsy [5], and a study on blood pressure related prognosis [6]. This allowed the analyses of the present study. The University Hospital Maastricht had an adherent population of approximately 190,000 people at that time. A brain infarct was defined as clinical signs of focal cerebral function disturbance with a sudden onset, lasting longer than 24 hours or leading to death, with no other apparent cause than that of vascular origin, and without signs of haemorrhage or bleeding on CT or MRI (except when diagnosed as haemorrhagic infarction), or autopsy revealing an infarct compatible with the clinical signs and symptoms.

Table 1. Medication at admission.

\begin{tabular}{|c|c|c|c|c|c|c|c|}
\hline \multirow[t]{2}{*}{ Medication } & $\begin{array}{l}\text { Lacunar } \\
\mathbf{N}=\mathbf{3 7 0}\end{array}$ & \multicolumn{2}{|c|}{$\begin{array}{l}\text { Thrombo-embolic } \\
\mathrm{N}=421\end{array}$} & \multicolumn{2}{|c|}{$\begin{array}{l}\text { Cardio-embolic } \\
\mathrm{N}=\mathbf{2 2 2}\end{array}$} & \multicolumn{2}{|c|}{$\begin{array}{l}\text { Total } \\
\mathbf{N}=1013\end{array}$} \\
\hline & $\mathrm{N} \quad(\%)$ & $\mathrm{N}$ & $(\%)$ & $\mathrm{N}$ & $(\%)$ & $\mathrm{N}$ & $(\%)$ \\
\hline$\beta$-blockers & 55 (14.9) & 69 & $(16.4)$ & 58 & $(26.1)$ & 182 & $(18.0)$ \\
\hline Benzodiazepines & $37(10.0)$ & 68 & $(16.2)$ & 31 & $(14.0)$ & 136 & (13.4) \\
\hline a2-blockers & $8 \quad(2.2)$ & 6 & $(1.4)$ & 9 & $(4.1)$ & 23 & $(2.3)$ \\
\hline ACE-inhibitors & $50(13.5)$ & 44 & $(10.5)$ & 35 & $(15.8)$ & 129 & (12.7) \\
\hline Calciumantagonists & $29 \quad(7.8)$ & 41 & $(9.7)$ & 36 & $(16.2)$ & 106 & $(10.5)$ \\
\hline Xanthinederivatives & $14 \quad(3.8)$ & 19 & (4.5) & 11 & $(5.0)$ & 44 & (4.3) \\
\hline Histamineantagonists & $24 \quad(6.5)$ & 25 & (5.9) & 8 & (3.6) & 57 & (5.6) \\
\hline Corticosteroids & $15 \quad(4.1)$ & 21 & $(5.0)$ & 11 & $(5.0)$ & 47 & (4.6) \\
\hline Vasodilators & $50(13.5)$ & 79 & $(18.8)$ & 47 & $(21.2)$ & 176 & (17.4) \\
\hline Diuretics & $85(23.0)$ & 106 & $(25.2)$ & 92 & (41.4) & 283 & $(27.9)$ \\
\hline
\end{tabular}


All patients were examined as soon as possible after admission or at the first outpatients' clinic visit. Patients had routine investigations including standard blood and urine tests, electrocardiography, chest radiography, carotid ultra-sound studies (not in all patients), and cerebral CT scan. We noted the vascular risk factors hypertension, diabetes mellitus, and a history of ischemic heart disease [4]. After combining $\mathrm{CT}$ and clinical information patients were assigned to one of three brain infarct subtypes: lacunar, atherothrombotic, or cardioembolic infarcts [4]. Apart from these three types a separate group with rare causes, such as cerebral vasculitis, carotid artery dissection, fibromuscular dysplasia, coagulation disorders, Moya Moya disease, venous occlusion, etc., was noted, but not included in this study because it was too heterogeneous to fit our study aim. Lacunar infarct (LACI) was defined as an acute stroke syndrome with a CT lesion compatible with a lacunar infarct, consisting of a subcortical small sharply demarcated hypodense lesion with a diameter less than $15 \mathrm{~mm}$. If no such lesion was visible, or if no CT was performed we used the established criteria of unilateral motor and/or sensory signs that involved all or at least two of the three body parts (face, arm, leg) without disturbance of consciousness, visual fields, language, or other cortical functions. We distinguished four lacunar syndromes: pure motor stroke, sensorimotor stroke, pure sensory stroke, and ataxic hemiparesis/dysarthria -clumsyhand syndrome [7]. Earlier we showed good prediction of a lacunar infarct from the lacunar syndrome, provided such prediction is done by experts or with the use of a standard symptom list [8,9, Chapter four in this thesis]. Atherothrombotic infarct (AT) was defined as an acute stroke syndrome with CT findings compatible with an infarct involving the cortex. In the absence of such or when no CT was performed we used established clinical criteria consisting of unilateral motor and/or sensory symptoms in combination with signs of disturbance of consciousness, visual fields, language, or other cortical functions. Also, patients with an isolated mono-paresis were included as well as patients with incomplete involvement of two body parts, or with isolated cortical dysfunction (mostly aphasia), as where those with a large, deeply located (striatocapsular) infarct on CT. A cardioembolic infarct (CE) was defined as an acute stroke syndrome with CT findings compatible with an infarct involving the cortex or a cortical stroke syndrome, with present or prior atrial fibrillation, a recent myocardial infarct (less than 6 weeks), prosthetic valve, endocarditis, cardiomyopathy, mitral stenosis, left ventricular aneurysm, or intracardiac thrombus. Patients with stroke fitting the criteria for lacunar infarction were classified as lacunar, despite the presence of a potential cardioembolic stroke source. Large subcortical (striatocapsular) infarcts were either atherothrombotic or cardioembolic, depending on the presence of a cardioembolic stroke source. Medication on admission was registered and grouped by class, according to the drugs chemical structure or pharmacological action. The following ten groups of commonly used drugs were used in this study: betablockers, benzodiazepines, central acting antihypertensive drugs ( $\alpha 2$-blockers), ACE-inhibitors, calcium antagonists, xanthine-derivatives, histamine antagonists, corticosteroids, vasodilators, and diuretics. We used the modified Rankin scale on admission as a measure of stroke severity. Although not validated for this purpose, 
this allowed us to compare individual patient data at stroke onset and at 3-month follow-up in another study [4].

Baseline stroke severity was considered in three degrees: mild (Rankin 0,1 and 2), moderate (Rankin 3), and severe impairment (Rankin 4 and 5). Functional outcome at three months was rated using the dichotomised modified Rankin scale as functional independent (Rankin 0, 1, and 2) or functional dependent or dead (Rankin 3, 4 , and 5 , or 6 ). Odd ratios were determined to estimate the chance of functional independence at three months in the different medication groups. Analyses were done univariate and multivariate with a logistic regression model with age, sex, hypertension, diabetes mellitus, and stroke severity (based on Rankin score on admission) as independent prognostic variables; all analyses were done for the different stroke subtypes separately.

Table 2. Rankin scores

\begin{tabular}{|c|c|c|}
\hline Rankin & $\begin{array}{l}\text { Rankin at stroke onset } \\
\text { N }(\%)\end{array}$ & $\begin{array}{l}\text { Rankin at } 3 \text { months } \\
\mathrm{N} \quad(\%)\end{array}$ \\
\hline $\mathbf{0}$ & 0 & $61 \quad(6.0)$ \\
\hline 1 & $28 \quad(2.8)$ & $166(16.4)$ \\
\hline 2 & $214(21.1)$ & $278(27.4)$ \\
\hline 3 & $266(26.3)$ & $171(16.9)$ \\
\hline 4 & $215(21.2)$ & $112(11.1)$ \\
\hline 5 & $290(28.6)$ & $88 \quad(8.7)$ \\
\hline 6 & 0 & $137(13.5)$ \\
\hline Total & $1013(100)$ & $1013(100)$ \\
\hline
\end{tabular}




\section{Results}

Of the 1051 patients, 36 had a rare stroke cause and were excluded from the analyses. Of the remaining 1015 patients, two $(0.2 \%)$ were lost to follow-up at three months following stroke, leaving 1013 patients for final analyses, of whom 533 $(52.6 \%)$ were male. Mean age was 70.5 (SD 11.9) years; median age was 72 (range 24-96) years. Three-hundred-and -seventy patients $(36.5 \%)$ had a lacunar, and 643 $(63.5 \%)$ had a territorial infarct. Of these $643,222(34.5 \%)$ had a potential cardioembolic infarct cause, whereas the remaining $421(65.5 \%)$ had large vessel disease as the most likely cause, and were assigned to the AT subtype. Stroke severity on admission was mild in $242(23.9 \%)$, moderate in $266(26.3 \%)$ and severe in 505 patients $(49.9 \%)$. Medication use on admission is shown in table 1 . At three months 505 patients (49.9\%) were functionally independent, $371(36.6 \%)$ were functionally dependent, whereas 137 patients $(13.5 \%)$ had died. Rankin scores on admission and at three months are shown in table 2 . The variables that emerged as predictor of outcome in the univariate analysis are shown in table 3 . These variables were used in the multivariate models. In lacunar stroke, logistic regression analyses showed that vasodilator use remained unfavourably associated with functional independence at three months (OR 0.37, 95\%CI 0.16-0.89; $\mathrm{p}=0.025$ ). The use of ACE-inhibitors, corticosteroids, and diuretics had no longer predictive value with regard to outcome in the multivariate analyses. In the AT stroke group the use of diuretics remained unfavourably associated with functional independence at three months (OR 0.43, 95\%CI 0.22-0.82; $\mathrm{p}=0.010$ ). Vasodilators did not remain independently associated with outcome in the multivariate analyses. In the cardioembolic stroke group the use of calcium antagonists remained independently associated with better outcome at three months (OR 2.64, 95\%CI 1.04-6.69; $\mathrm{p}=0.042$ ). 
Table 3. Univariate analyses: chance on good outcome for the different possible risk factors. For the different medication groups only the significant results are shown.

\begin{tabular}{lllllllllll}
\hline Risk factor & LACI & \multicolumn{3}{c}{ AT } & \multicolumn{5}{c}{ CE } \\
& OR & $\mathbf{9 5 \% C I}$ & p-value & OR & $\mathbf{9 5 \% C I}$ & p-value & OR & $\mathbf{9 5 \% C I}$ & p-value \\
\hline Age $<75$ years & $3.58(2.24-5.72)$ & 0.000 & 2.88 & $(1.88-4.41)$ & 0.000 & 1.96 & $(1.12-3.43)$ & 0.018 \\
Male sex & $1.29(0.83-2.01)$ & NS & 1.85 & $(1.24-2.76)$ & 0.002 & 2.36 & $(1.34-4.16)$ & 0.003 \\
Ischemic heart disease & $0.56(0.33-0.94)$ & 0.027 & 1.30 & $(0.84-2.01)$ & NS & 0.98 & $(0.54-1.78)$ & NS \\
Hypertension & $0.59(0.38-0.91)$ & 0.017 & 0.64 & $(0.43-0.95)$ & 0.025 & 0.76 & $(0.43-1.32)$ & NS \\
Diabetes mellitus & $0.53(0.30-0.92)$ & 0.022 & 0.47 & $(0.27-0.81)$ & 0.006 & 0.49 & $(0.24-1.03)$ & NS \\
ACE-inhibitors & $0.49(0.27-0.90)$ & 0.019 & NS & & & NS & & \\
Calcium antagonists & NS & & & NS & & & 2.10 & $(1.02-4.32)$ & 0.041 \\
Corticosteroids & $0.29(0.10-0.84)$ & 0.016 & NS & & & NS & & \\
Vasodilators & $0.40(0.22-0.74)$ & 0.003 & 0.48 & $(0.28-0.83)$ & 0.007 & NS & & \\
Diuretics & $0.54(0.33-0.89)$ & 0.015 & 0.30 & $(0.18-0.50)$ & 0.000 & NS & & \\
\hline
\end{tabular}

\section{Discussion}

Of the ten different drug categories that we distinguished, only three were independently associated with stroke outcome at three months: the use of vasodilators influenced prognosis unfavourably in lacunar stroke, as did the use of diuretics in atherothrombotic stroke. The use of calcium antagonists had a favourable effect on functional outcome in cardioembolic stroke patients. Various past clinical trials showed no effect on functional outcome of calcium antagonists in acute stroke $[10,11]$. However, all these clinical trials had a time window for the administration of calcium antagonists of at least three hours. In our study, patients were using calcium antagonists at the time of stroke occurrence. Timing of administering this drug is likely to be crucial for any eventual beneficial effect. The time window of therapeutic opportunity may be rather short, whereas massive calcium influx takes place in the first minutes after the onset of ischemia, which leads irreversibly and independently of further calcium influx to brain damage $[12,13]$. The beneficial effect of calcium antagonists given prophylactically in subarachnoid haemorrhage may in part relate to this issue of timing. The fact that the favourable effect of calcium antagonists was only found in cardioembolic stroke may in part relate to the high rate of up to $70 \%$ of spontaneous reperfusion in this group [14]. Reperfusion may 
be conditional for a drug to exert its potential neuroprotective effect. In nonembolic stroke subtypes spontaneous reperfusion is less likely, and therefore the chance of neuroprotection may be too. The therapeutic effect of another drug type, which is diazepam, in only cardioembolic stroke favours this idea concerning requirement of reperfusion for neuroprotective efficacy of a drug [15].

Vasodilators may dilate cerebral blood vessels that supply not-affected areas, with the risk of a 'steal' phenomenon and consequently a further decreased perfusion of an already compromised region. However, it is unclear why such phenomenon should only occur in lacunar stroke, but this may relate to poor collateral blood supply in the areas supplied by the deep brain perforators. The finding that the use of diuretics affected outcome unfavourably may relate to an increase in blood viscosity by this drug type [17]. Why we found such effect confined to atherothrombotic stroke type remains unclear. One possible explanation is that the use of diuretics in lacunar and cardioembolic stroke types was linked with other conditions, which by themselves are more strong predictors of prognosis, thus masking any impact of the drug. Such factor may be more severe hypertension in lacunar stroke, and congestive heart failure in cardioembolic stroke. Our data favour the idea that diuretics and vasodilators may rather be avoided as first choice drugs in the treatment of elevated blood pressure following TIA or stroke.

The use of ACE-inhibitors worsened prognosis in lacunar stroke, but this was not an independent effect. Whether ACE- inhibition results in benefit or harm regarding stroke outcome, may theoretically depend upon the balance in activation by these drugs of either eNOS, or nNOS and iNOS. eNOS is produced in the vascular wall and is thought to be neuroprotective in brain ischemia, this in contrast with nNOS and iNOS that is produced in neurones and leukocytes respectively and that according to the excitotoxicity concept is detrimental for brain tissue. ACE inhibitors prevent the degradation of the vasodilatory bradykinine that activates endothelial Nitric Oxide Synthethase (eNOS) in the vascular wall. It is however not a specific activator of eNOS but also activates nNOS and iNOS. The issue is of clinical relevance as ACE inhibition may increasingly be used to lower blood pressure in secondary stroke prevention because of the results of the PROGRESS trial [16]. It is unknown whether such use may worsen outcome should a stroke occur despite secondary preventive measures, an issue that should be considered in any phase IV study on ACE inhibition. However, our results do not suggest that the use of an ACE inhibitor at the time of stroke occurrence worsens stroke outcome significantly.

The use of corticosteroids also had a relation, although not independent, with poor outcome. This finding is in line with earlier clinical trials were no effect on outcome was shown. $[18,19]$. Probably serious steroid-related side effects outweigh the expected positive effects on vasogenic edema and inflammation.

The use of vasodilators in lacunar stroke, and that of diuretics in atherothrombotic stroke were independently related to unfavourable outcome at three months.

We failed to detect an independent effect of benzodiazepines on functional outcome at three months. Nevertheless, at least theoretically, benzodiazepines are promising neuroprotective drugs that inhibit glutamate release and prevent the effects of glutamate and neuronal NO later in the excitotoxic cascade $[20,21$, Chapter two in this 
thesis]. To observe such effect, a rather high dose of benzodiazepines was needed in experimental focal ischemia, and only when it was administered after rather than before stroke onset [21, Chapter two in this thesis]. The present analysis focused on the effect of benzodiazepines present when the stroke occurred. Earlier we detected a correlation between good functional outcome and the use of benzodiazepines during the first three days after stroke onset [22]. Timing of the optimal benzodiazepine dose is probably crucial, and our experimental data suggest that the window of opportunity coincides with the upregulation of NO, which starts one to five hours after stroke [23]. This may explain the difference between our present and earlier findings. The dose may also play a role. High doses of diazepam were probably not administered in the first hours after stroke by caregivers. The results of the EGASIS trial suggest benefit of early diazepam use, especially in cardioembolic stroke [15]. In this trial most of the patients received the drug rather late, which would considering its mode of action, not be a disadvantage over administration very soon after stroke onset. In any case, withdrawal of benzodiazepines in the acute stroke phase should be avoided, as this increases the risk of early post-stroke seizures almost ten times [5].

We failed to establish any effect on stroke outcome of beta-blockers, alpha2blockers, xanthine derivatives, and histamine antagonists. Our results do not urge these drug categories to be tested in clinical trials, despite eventual theoretical arguments. On the other hand it is reassuring that there seems not to be any harm in their use, at least when looking at short-term stroke outcome. Some drugs may theoretically influence brain plasticity and consequent functional recovery, but such effect may well depend on timing, dose, and duration of their use [24].

Our study has its shortcomings. To find a significant effect of drugs on functional outcome subgroups should be large. Some drugs were only taken by a few patients, and, therefore we could have missed possible effects of these drugs on outcome. Further, from the view of neuroprotection it may be less relevant to evaluate the effects of certain drugs that were already present at stroke onset than medication started later because pragmatically, the first approach leaves no opportunity for a therapeutical time window for drug administration as a future therapy. Only for a subgroup of patients, we collected data on drug use from stroke onset to 28 days post-stroke in an earlier study [5]. Depending on the mode of action, absence of an effect of a drug present at stroke onset, may not exclude an effect when the drug is present at some time after stroke onset, as is discussed above for diazepam.

We analysed the effects of drugs for different stroke subtypes separately, rather than using stroke subtype as an independent variable affecting prognosis in our models. The reason is that stroke subtype is not only a strong independent predictor of outcome, but also the underlying pathology and its manifestation over time differ between these subtypes, and so may any effect of drugs on these processes as well.

Although in the analyses we accounted for differences between the groups with or without a certain drug use regarding various prognostic variables, it is unlikely that this completely separated the effects of the drugs from that of the underlying conditions that fostered their prescription. However, in an observational study this is probably the best one can do. 
Our data may have clinical implications for the treatment of high blood pressure, following TIA or ischemic stroke: In patients with a high stroke risk, be it lacunar or large vessel disease, vasodilators and diuretics may better be avoided. Other drugs may be used without harm. Calcium antagonists on the other hand may exert benefit in patients with an increased risk for cardioembolic stroke, and may become drugs of first choice in these patients. 


\section{References.}

1. Massing MW, Rywik SL, Jasinski B, Manolio TA, Williams OD, Tyroler HA. Opposing national stroke mortality trends in Poland and for African Americans and whites in the United States, 1968 to 1994. Stroke. 1998; 1366-72.

2. www.CBS.nl

3. Goldstein LB. Influence of common drugs and related factors on stroke outcome. Curr Opinion Neurol. 1997;10:52-57.

4. de Jong G, van Raak L, Kessels F, Lodder J. Stroke subtype and mortality. a follow-up study in 998 patients with a first cerebral infarct. J Clin Epidemiol. 2003: 262-8.

5. Heuts-van Raak L. Seizure risk and peri-stroke medication use. Chapter 6 in: Seizures following a first cerebral infarct. Risk factors and prognosis. Academic dissertation, ISBN 90-9009220-X, University of Maastricht, 1996.

6. Boreas AM, Lodder J, Kessels F, de Leeuw PW, Troost J. Prognostic value of blood pressure in acute stroke. J Hum Hypertens. 2002 Feb:111-116.

7. Bamford J, Sandercock P, Dennis M, Burn J, Warlow C. Classification and natural history of clinically identifiable subtypes of cerebral infarction. Lancet 1991: 1521-6.

8. Lodder J, Bamford J, Kappelle J, Boiten J. What causes false clinical prediction of small deep infarcts? Stroke. 1994: 86-91.

9. Aerden L, Luijckx GJ, Ricci S, Hilton A, Kessels F, Lodder J. Validation of the Oxfordshire Community Stroke Project syndrome diagnosis derived from a standard symptom list in acute stroke. J Neurol Sci. 2004: 55-8. (Chapter four of this thesis)

10. Pahor M, Psaty BM, Alderman MH, Applegate WB, Williamson JD, Cavazzini C, Furberg CD. Health outcomes associated with calcium antagonists compared with other first-line antihypertensive therapies: a meta-analysis of randomised controlled trials.Lancet. 2000:1949-54.

11. Horn J, Limburg M. Calcium antagonists for ischemic stroke: a systematic review. Stroke. 2001: $570-6$

12. Siesjo BK, Zhao Q, Pahlmark K, Siesjo P, Katsura K, Folbergrova J. Glutamate, calcium, and free radicals as mediators of ischemic brain damage. Ann Thorac Surg. 1995: 1316-20.

13. Kristian T, Gido G, Kuroda S, Schutz A, Siesjo BK. Calcium metabolism of focal and penumbral tissues in rats subjected to transient middle cerebral artery occlusion. Exp Brain Res. 1998: 503-9.

14. Hornig CR, Bauer T, Simon C, Trittmacher S, Dorndorf W. Hemorrhagic transformation in cardioembolic cerebral infarction. Stroke. 1993: 465-8.

15. Lodder J. van Raak L, Hilton A, Hardy E, Kessels A. Diazepam to improve acute stroke outcome: results of the early GABA-ergic activation study in stroke trial. A randomized doubleblind placebo-controlled trial. Cerebrovasc Dis. 2006;21:120-127.

16. PROGRESS Collaborative Group. Randomised trial of a perindopril-based blood-pressurelowering regimen among 6,105 individuals with previous stroke or transient ischaemic attack. Lancet. 2001: 1033-41. 
17. Weiss DJ, Evanson OA, Geor RJ. The effects of furosemide and pentoxifylline on the flow properties of equine erythrocytes: in vitro studies. Vet Res Commun. 1994;18(5):373-81.

18. Norris JW, Hachinski VC. High dose steroid treatment in cerebral infarction. BMJ. 1986; 292: 21-23.

19. De Reuck J, Vandekerchove T, Bosma G, De Meulemeester K, Van Landegem W, De Waele J, et al. Steroid treatment in acute ischaemic stroke: a comparative retrospective study of 556 cases. Eur Neurol. 1988; 28: 70-72.

20. Schwartz-Bloom RD, McDonough KJ, Chase PJ, Chadwick LE, Inglefield JR, Levin ED. Longterm neuroprotection by benzodiazepine full versus partial agonists after transient cerebral ischemia in the gerbil [corrected] Cereb Blood Flow Metab. 1998: 48-58.

21. Aerden LA, Kessels FA, Rutten BP, Lodder J, Steinbusch HW. Diazepam reduces brain lesion size in a photothrombotic model of focal ischemia in rats. Neurosci Lett. 2004: 76-8. (Chapter two of this thesis)

22. Lodder J, Heuts-van Raak L, Kessels F. GABA-ergic stimulation by benzodiazepines at stroke onset may ameliorate functional outcome in cardioembolic stroke patients. Cerebrovasc Dis. 1996;6:118.

23. Malinski T, Bailey F, Zhang ZG, Chopp M. Nitric oxide measured by a porphyrinic microsensor in rat brain after transient middle cerebral artery occlusion. J Cereb Blood Flow Metab. 1993 May: 355-8.

24. Goldstein LB. Potential effects of common drugs on stroke recovery. Arch Neurol. 1998;55:454456. 
CHAPTER 7

GENERAL DISCUSSION 


\section{General discussion}

In this thesis there is a clear division in a clinical and an experimental part. First we describe an experimental study in vivo in which the hypothesis is tested that diazepam is neuroprotective in focal brain ischemia, and that this neuroprotective effect depends on the time point of administration (Chapter two). Second we describe an experimental study in rat brain slices that indicates that diazepam apart from its GABA-ergic effect has new and unexpected effects in rat brain and cerebellum. The clinical part starts in chapter four with a study that validates the use of a standard scoring list, as used in the OCSP project, that allows distinction of stroke subtypes with different prognosis. In Chapter five the safety of early diazepam treatment in a large group of acute stroke patients is studied in a double-blind, placebo-controlled trial. Finally, in Chapter six, we describe an observational study of 1013 acute ischemic stroke patients, where the independent effect of various commonly used drugs on functional outcome at three months following stroke is studied.

To answer the question whether diazepam is neuroprotective in focal brain ischemia, in chapter two we studied the effect of diazepam treatment on infarct size in an animal model of focal ischemia: animals that received diazepam had smaller infarcts than controls. Surprisingly, neuroprotection was only evident when diazepam was given after the induction of the infarct. This suggests that diazepam has an inhibiting effect somewhat more downstream the excitotoxic cascade, and makes it unlikely that the protective effects of diazepam are just the result of GABA-ergic inhibition of glutamate release. As NO production starts after 20 minutes and reaches its maximum after four hours in focal brain ischemia [2], a more appealing explanation for the neuroprotective effect of diazepam is that it inhibits neuronal NOS directly in focal brain ischemia. An additional explanation relates to the fact that diazepam inhibits phosphodiesterases (PDE's), resulting in an accumulation of cGMP that is believed to be neuroprotective. Recently an association between the PDE4D gene and ischemic, particularly cardioembolic stroke was reported [3]. In chapter two we proved that diazepam is neuroprotective in a rat model of focal ischemia, and that probably a mechanism somewhat later in the excitotoxic cascade is responsible for this effect. In chapter three we attack the question what mechanism is responsible for the neuroprotective effects of diazepam. Therefore we studied the effect of diazepam on NO synthesis using rat cerebellar slices. Slices were incubated at $37.0^{\circ} \mathrm{C}$ to prevent an effect of diazepam induced hypothermia. The addition of diazepam in the incubation medium resulted in a dual effect on cGMPimmunofluorescence in the cerebellar slices. First, there was a large decrease in cGMP-immunofluorescence in the molecular and granule cell layers. The failure of bicucilline to block this effect indicates that not the well-known GABA-ergic effects of diazepam, but mechanisms somewhat later in the excitotoxic cascade play a role in this effect on cGMP. The fact that cGMP-immunofluorescence does not increase after the external addition of an NO-donor to the incubation medium must lead to the conclusion that diazepam inhibits the formation of cGMP irreversibly, independent from the extracellular NO-concentration. Diazepam could have a direct effect on guanylate-cyclase. If this effect only affects the soluble form of GC and 
not the particulate form that is found often in glial cells, we could explain the high cGMP levels found inside some astrocytes. Secondly, in slices that had been incubated in the presence of diazepam, we observed intense cGMP-immunostaining in astrocytes in the white matter tracts of the cerebellum, in the hippocampus, and in the cerebral cortex. This observation is reminiscent to the effect of rolipram on cGMP levels in hippocampal astrocytes. Rolipram is a highly selective inhibitor of the cAMP-specific PDE-4. Recently, diazepam has been reported to possess PDE-4 inhibiting properties [4]. It is possible that diazepam has a specific PDE-4 inhibiting effect on astrocytes in the rat brain.

As diazepam has a clear effect on infarct size in a rat model, further clinical testing should be done to reveal a neuroprotective effect in human stroke. Many promising neuroprotective agents have shown to decrease injury in animal models of ischemic stroke. The vast majority of these substances were aimed at the first steps of the ischemic cascade like the prevention of calciuminflux, inhibition of glutamate release, or blocking of the NMDA-receptor. All of these agents failed to prove their efficacy in prospective clinical trials. Probably they were administered too late to influence the first steps of the ischemic cascade that take place in the first hour from stroke onset. Clinical trials with hypothermia in general hypoxia after cardiac arrest on the contrary have proven to ameliorate outcome in global brain ischemia [10]. The only substance that has shown a slight neuroprotective effect in human ischemic stroke, apart from diazepam, is NXY-059, a potent free radical quenching agent [11]. This supports our hypothesis that for a substance to have a clinical relevant neuroprotective effect in ischemic stroke, it should have an effect later in the excitotoxic cascade. We made it very plausible in chapter two and three that diazepam has these effects apart from the expected and well known GABA-ergic effect that inhibits the release of glutamate. This explains why other GABA-ergic drugs failed to prove their neuroprotective effect in human stroke [12].

Any effect of a neuroprotective agent may depend on stroke subtype. A large territorial infarct differs in many aspects from a lacune. A clinical scoring system is therefore mandatory to allow pre-defined subgroup analyses in acute stroke trials. In chapter four we studied whether the Oxfordshire Community Stroke Project (OCSP) classification allows distinction of stroke subtypes with different prognosis. The data show that the standard list of neurological signs scored acceptably well as a clinical test to predict expert clinical syndrome diagnosis. Concordance expressed by kappa was 'fair' for PACS, and 'substantial' for LACS and TACS. Our data show that standard listing of neurological signs on early stroke patient assessment has an acceptable validity when compared with expert clinical diagnosis for different stroke subtypes identified by OCSP syndrome diagnosis. It should be noted that the OCSP syndrome diagnosis was targeted at ischemic stroke, whereas distinction between brain infarct and haemorrhage can only reliably be made with the aid of CT or MRI.

In chapter five, as a part of a large clinical trial, we studied whether the administration of diazepam in acute stroke is safe. We found in over one-third of our stroke patients in both treatment groups at least one of the defined potential treatment side effects, most of these 'side effects' should likely to be taken as regular complications of stroke. The number of 'serious adverse events', premature treatment dis- 
continuations, and the number of patients who needed the diazepam antidote flumazenil did not differ between the two groups. However, when we analysed ischemic and haemorrhagic stroke separately, differences emerged. First of all, respiratory depression together with pneumonia was rather low (not statistically significant) in at least the diazepam treated infarct patients. In those with $\mathrm{ICH}$, however, pneumonia was registered significantly more often in the diazepam group. The lower number of patients with urinary tract infections in this group may possibly relate to a more frequent use of antibiotics, but this remains speculative. Surprisingly, paradoxical reactions like confusion, were more prevalent in the placebo group, which may be due to chance alone. There was a lower (statistically significant) stroke recurrence rate in the diazepam treated infarct group. This may be a chance effect, but may also relate to the depressor effect of diazepam on the stroke related enhanced sympathetic activity, thereby lowering the chance of cardiac complications such as myocardial infarction or arrhythmia induced stroke recurrence. Our data sustain the idea that it is unnecessary to stop the use of a benzodiazepine when a stroke occurs. Not only is continuation for at least a few days without harm, it even may have a beneficial effect.

In chapter six we studied the use of various drugs at stroke onset as independent predictors of outcome at three months. Of the ten different commonly used drug categories that we studied only three were independently associated with stroke outcome at three months: use of vasodilators in lacunar stroke, and the use of diuretics in atherothrombotic stroke influenced prognosis unfavourably, whereas use of calcium blockers had a favourable effect on functional outcome in cardio-embolic stroke. Vasodilators may cause a 'steal' phenomenon and consequently a further decreased perfusion of an already compromised region. Diuretics may increase blood viscosity [5]. This could mean that diuretics might rather be avoided as first choice drugs in the treatment of elevated blood pressure following TIA or stroke. Calcium antagonists had a favourable effect on outcome in cardioembolic stroke patients. Various past clinical trials showed no effect on functional outcome of calcium antagonists in acute stroke [6,7]. In our study, patients were using calcium antagonists at the time of stroke occurrence. The issue of timing might be essential for a beneficial effect of calcium blockers. In subarachnoid haemorrhage calcium blockers are given prophylactically, this may also in part relate to their beneficial effect. The favourable effect we found only in cardioembolic stroke may further relate to the high rate of spontaneous reperfusion in this group. The therapeutic effect of diazepam in only cardioembolic stroke in the EGASIS-trial favours this idea concerning requirement of reperfusion for neuroprotective efficacy of a drug. The use of ACE-inhibitors worsened prognosis in lacunar stroke, but this was not an independent effect. Whether ACE- inhibition results in benefit or harm regarding stroke outcome, may theoretically depend upon the balance in activation by these drugs of either eNOS, or nNOS and iNOS. This issue is of clinical relevance as ACE inhibition may increasingly be used to lower blood pressure in secondary stroke prevention because of the results of the PROGRESS trial [8]. It is unknown whether such use may worsen outcome should a stroke occur despite secondary 
preventive measures, an issue that should be considered in any phase IV study on ACE inhibition.

The use of corticosteroids also had a relation, although not independent, with poor outcome. Probably there is a balance between the expected positive effect on inflammation and edema of this drug in the penumbra, and serious systemic side effects that influence prognosis.

We failed to detect an independent effect of benzodiazepines on functional outcome at three months in this study, probably explained by the fact that the present analysis focussed on the effect of benzodiazepines present when the stroke occurred. In contrast earlier we detected a correlation between good functional outcome and the use of benzodiazepines during the first three days after stroke onset [9]. Our experimental data, described in Chapter two, suggest that the window of opportunity for diazepam starts one to five hours after stroke. In the EGASIS trial most of the patients received the drug rather late which would, considering its mode of action, not be a disadvantage over administration very soon after stroke onset. In any case, withdrawal of benzodiazepines in the acute stroke phase should be avoided, as this increases the risk of early post-stroke seizures almost ten times. We failed to establish any effect on stroke outcome of beta-blockers, alpha2-blockers, xanthine derivatives, and histamine antagonists. On the other hand it is reassuring there seems not to be any harm in their use, at least when looking at short-term stroke outcome.

In summary: In our experimental studies we found strong indications that diazepam is neuroprotective in an animal model of focal ischemia. Apart from the well known GABA-ergic effects of diazepam, we found an effect of diazepam on NO mediated cGMP levels in rat brain slices, incubated at 37.0 C. These effects of diazepam probably on PDE and sGC are new and practically unknown. This makes diazepam a very interesting drug not only for it's use in ischemic stroke, but also in many other diseases. If we can confirm these pharmacological effects in further experimental studies, new indications for the use of this old-fashioned and wellknown drug will be found soon. Further we proved that in ischemic stroke timing of diazepam administration is essential. The window of therapeutic opportunity is probably between one and five hours from stroke onset. This wide time window makes diazepam a very attractive potential neuroprotective agent.

In our clinical studies we proved that the OCSP scoring list can be used to make a distinction of stroke subtypes with different prognosis. The safety study of chapter five is essential for any possible use of diazepam in acute stroke in the clinical setting and was part of the EGASIS study. Chapter six is an invitation to perform trials with other commonly used drugs in stroke, and to use our experimental model of focal ischemia. Further we warn to be reluctant with the administration of certain drugs in the clinical setting of acute ischemic stroke.

We conclude that diazepam treatment is a rational and promising strategy for neuroprotection in acute stroke with a possible time window of therapeutic opportunity of several hours. Such treatment could also be useful to prolong the time window for trombolysis. Probably diazepam has an effect simultaneously on multiple steps in the ischemic cascade. Inhibitors of PDE4, free radical scavengers and agents 
influencing cGMP are all substances that should have our attention the coming years. The EGASIS-trial was a big step in the right direction to prove a favourable effect of diazepam on functional outcome in human ischemic stroke beyond any doubt, but missed statistical power [1]. It is important to remember that to prove the beneficial effect of aspirin in the prevention of stroke large multicentre trials and meta-analyses were necessary. Therefore, future large trials should be planned to prove diazepam's clinical relevance in acute ischemic stroke. Further we found an indication that diuretics and vasodilators may rather be avoided as first choice drugs in the treatment of elevated blood pressure in high risk patients following TIA or stroke. 


\section{References}

1. Lodder J. van Raak L, Hilton A, Hardy E, Kessels A. Diazepam to improve acute stroke outcome: results of the early GABA-ergic activation study in stroke trial. A randomised doubleblind placebo-controlled trial. Cerebrovasc Dis. 2006; 21:120-127.

2. Malinski T, Bailey F, Zhang ZG, Chopp M. Nitric oxide measured by a porphyrinic microsensor in rat brain after transient middle cerebral artery occlusion. J Cereb Blood Flow Metab. 1993 May: 355-8.

3. Woo D, Kaushal R, Kissela B, Sekar P, Wolujewicz M, Pal P, Alwell K, Haverbusch M, Ewing I, Miller R, Kleindorfer D, Flaherty M, Chakraborty R, Deka R, Broderick J. Association of Phosphodiesterase 4D with ischemic stroke: a population-based case-control study. Stroke. 2006; 37: 371-6.

4. Collado, M.C., Beleta, J., Martinez, E., et al 1998. Functional and biochemical evidence for diazepam as a cyclic nucleotide phosphodiesterase type 4 inhibitor. Br. J. Pharmacol. 123: $1047-$ 54 .

5. Weiss DJ, Evanson OA, Geor RJ. The effects of furosemide and pentoxifylline on the flow properties of equine erythrocytes: in vitro studies. Vet Res Commun. 1994; 18: 373-81.

6. Pahor M, Psaty BM, Alderman MH, Applegate WB, Williamson JD, Cavazzini C, Furberg CD. Health outcomes associated with calcium antagonists compared with other first-line antihypertensive therapies: a meta-analysis of randomised controlled trials.Lancet. 2000:1949-54.

7. Horn J, Limburg M. Calcium antagonists for ischemic stroke: a systematic review. Stroke. 2001: $570-6$.

8. PROGRESS Collaborative Group. Randomised trial of a perindopril-based blood-pressurelowering regimen among 6,105 individuals with previous stroke or transient ischaemic attack. Lancet. 2001: 1033-41.

9. Lodder J, Heuts-van Raak L, Kessels F. GABA-ergic stimulation by benzodiazepines at stroke onset may ameliorate functional outcome in cardioembolic stroke patients. Cerebrovasc Dis. 1996; 6: 118.

10. The Hypothermia After Cardiac Arrest Study Group. Mild therapeutic hypothermia to improve the neurologic outcome after cardiac arrest. N Engl J Med 2002: 346: 549-556.

11. Lees KR, Zivin JA, Ashwood T, Davalos A, Davis SM, Diener HC, Grotta J, Lyden P, Shuaib A, Hardemark HG, Wasiewski WW; Stroke-Acute Ischemic NXY Treatment (SAINT I) Trial Investigators. NXY-059 for acute ischemic stroke. N Engl J Med. 2006: 9; 354(6): 588-600.

12. Lyden P, Shuaib A, Ng K, Levin K, Atkinson RP, Rajput A, Wechsler L, Ashwood T, Claesson L, Odergren T, Salazar-Grueso E; CLASS-I/H/T Investigators. Clomethiazole Acute Stroke Study in ischemic stroke (CLASS-I): final results. Stroke. 2002; 33(1): 122-8. 


\section{DANKWOORD}




\section{Dankwoord}

Aan deze promotie heb ik vele jaren gewerkt met hulp van velen, enkelen wil ik hier noemen omdat zij een bijzondere rol hebben gespeeld:

Jan Lodder, ik weet niet hoe ik jou moet bedanken, jij hebt me al die jaren bij de hand genomen en vele deuren voor me geopend. Een betrouwbare steun en toeverlaat in het moeilijke proces van een promotie. Het spijt mij dat jij de laudatio niet zelf kunt uitspreken, en dat je niet naast mij zit tijdens de verdediging van mijn thesis.

Harrie Steinbusch, altijd enthousiast heb jij mij alle mogelijkheden en hulp geboden om mijn laboratoriumonderzoek te kunnen doen. Altijd bereid tot overleg, of het nu in Maastricht, Nijmegen of Uppsala was. Jij had voor elk probleem wel een creatieve oplossing

Lisette, zonder jouw hulp, en praktische tips was het me nooit gelukt. Nooit was het te veel moeite om nog eens in de orginele databestanden of zelfs patiëntendossiers te zoeken naar ontbrekende data. Jij bent eigenlijk steeds mijn wetenschappelijke geweten geweest. Steeds weer zette jij de puntjes op de i, en hield je me voor dat het nog preciezer moest. Vooral de laatste weken waren intensief. Hartelijk dank voor je onmisbare steun.

Fons, wat een geduld heb jij moeten opbrengen om steeds weer opnieuw uit te leggen waarom de gebruikte statische methode het beste was, en om binnen enkele minuten getallen tevoorschijn te toveren waar ik al weken naar aan het zoeken was. Hartelijk dank voor je denkwerk en morele steun.

Hans Vles, hartelijk dank voor je substantiële bijdrage, en je steun op de goede momenten. Door jou is ook de $\mathrm{Ph}$ van mijn $\mathrm{PhD}$ gedekt.

Jan de Vente, hartelijk dank voor de inhoudelijke uitleg. Jij had steeds een passende verklaring voor de toch wel bijzonder bevindingen die ik deed, langzaamaan heb ik zo inzicht gekregen in de wondere wereld van het cGMP.

In het laboratorium wil ik verder iedereen bedanken met wie ik heb samengewerkt: Marianne, ik heb genoten van de samenwerking in het lab. Hellen bedankt. Wiel, bedankt voor de vele uurtjes die we samen in de kelder hebben doorgebracht waar we door de ratten werden besnuffeld. $\mathrm{Na}$ een moeizame start liep het model uiteindelijk als een trein.

Bart, dankjewel voor de hulp, met name bij het eindeloze snijden van coupes. Erik bedankt voor het plaatje van het cerebrale infarct. Anita dankjewel voor het gebruik van je data. Door jou was ik altijd goed op de hoogte van alles wat er speelde in het AZM.

Lahcin, als student ging je helemaal mee naar Brussel om een diermodel te leren kennen. Fantastisch om je later als collega te hebben gehad in Heerlen. 
Natuurlijk ook heel veel dank aan de maatschap Neurologie in Heerlen die een financiële bijdrage heeft geleverd aan mijn tijd in het laboratorium. Met name wil ik Peter Koehler en Cees Franke noemen die mij als opleiders toch ook wetenschappelijk hebben gevormd.

Als laatste wil ik mijn familie hier noemen: mijn ouders die mij altijd gestimuleerd hebben om mijn talenten te benutten, ook toen het niet zo voor de hand lag dat ik een academische carrière zou volgen. Oom Guust wil ik ook bedanken voor de brede interesse die hij mij heeft bijgebracht voor de wereld om mij heen.

Mirjam, wat een geluk is het om te kunnen leven met een vrouw zoals jij, die mij onvoorwaardelijk steunt in soms toch wel moeilijke tijden. Aan jou en aan Wouter draag ik dit boekje op. 


\section{CURRICUlum VitAE}




\section{Curriculum Vitae}

Leo Aerden is geboren op 9 mei 1968 te Roosendaal. Hij komt uit een groot gezin van vijf kinderen met een Spaanse moeder en een Nederlandse vader. Hij groeide op in Brunssum. Na het met lof afronden van de MAVO aan het Jongenspensionaat bij de broeders in Bleijerheide (Kerkrade), stroomde hij door naar de HAVO en het VWO aan het Sintermeertencollege te Heerlen. In 1989 werd hij direct ingeloot voor de studie geneeskunde aan de toenmalige Rijksuniversiteit Limburg. (thans Universiteit Maastricht) Zijn propedeuse en doctoraal haalde hij met genoegen. Na het behalen van zijn artsenbul in 1995 werkte hij vier maanden als AGNIO chirurgie te Sittard. Hierna volgde een periode als AGNIO neurologie in het Academisch Ziekenhuis Maastricht. In 1996 maakte hij de overstap naar het Atrium Ziekenhuis te Heerlen waar hij na anderhalf jaar, onder leiding van dr. C.L. Franke, zijn opleiding tot neuroloog kon beginnen. In deze periode verrichtte hij aan de afdeling Traumatologie van het Klinikum te Aken onder leiding van prof.dr. M. Magin dierexperimenteel onderzoek naar de fusie van wervels met gebruik van osteogenic protein (OP-1) bij schapen. Later liep hij nog een stage neurochirurgie aan het Klinikum te Aken. Ook de afdeling radiochirurgie (gamma-knife) van het Klinikum leerde hij goed kennen door de enthousiaste begeleiding van dr. A. van Oosterhout. Een deel van zijn opleiding heeft hij gevolgd in het AZM te Maastricht onder leiding van prof.dr. J. Troost. Tijdens deze periode startte hij onder leiding van prof.dr. H.W.M Steinbusch en dr. J. Lodder een promotieonderzoek naar de neuroprotectieve effecten van diazepam bij een ischemische beroerte. Dit resulteerde in meerdere publicaties en deze dissertatie. Na het afronden van zijn opleiding tot neuroloog in 2003 werkte hij een jaar als chef de clinique in het Rode Kruis Ziekenhuis te Den Haag dat later fuseerde met het Leyenburg ziekenhuis tot het HAGA ziekenhuis. Op 1 januari 2005 trad hij toe tot de maatschap neurologie in het Reinier de Graafgasthuis te Delft, waar hij zijn vak nu met veel plezier uitoefent. 
